
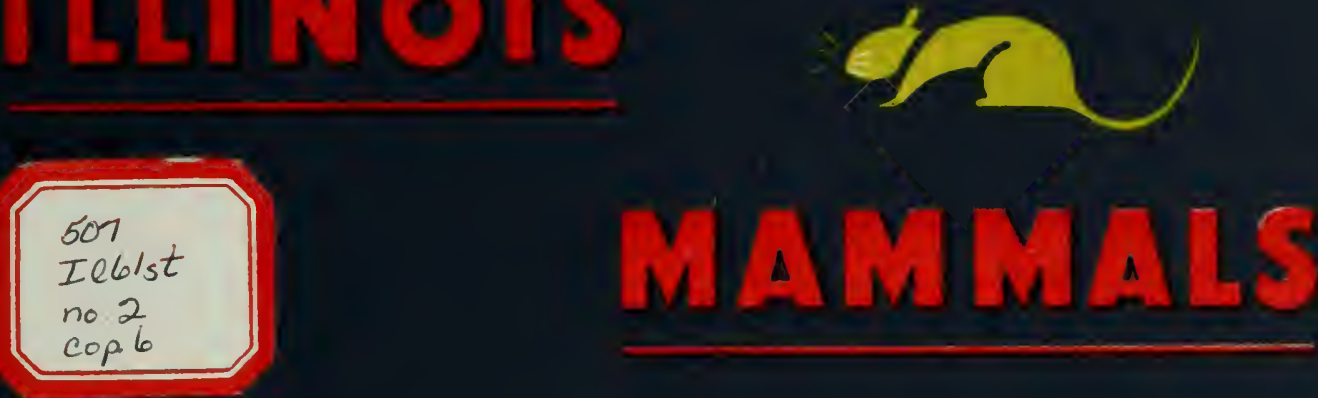

VIRGINIAS EIFERT

ILINOIS STATE MUSEUM
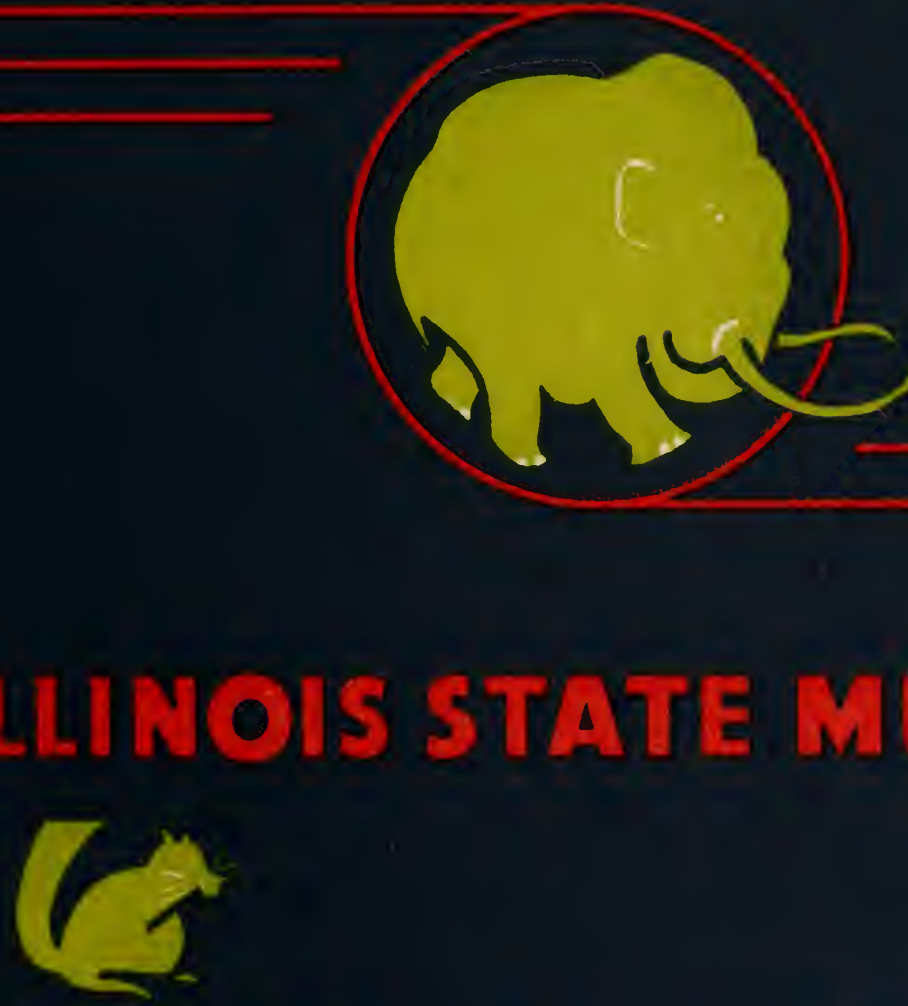

$$
\begin{aligned}
& \text { STORY OF ILLINOIS } \\
& \text { NO. } 2
\end{aligned}
$$




\section{STORY OF ILLINOIS SERIES}

No. 1 Story of Illinois: Indian and Pioneer, by V. S. Eifert

No. 2 Mammals of Illinois Today and Yesterday, by V. S. Eifert

No. 3 Exploring for Mushrooms, by V. S. Eifert

No. 4 Flowers that Bloom in the Spring, by V. S. Eifert

No. 5 Invitation to Birds, by V. S. Eifert

No. 6 Man's Venture in Culture, by Thorne Deuel

No. 7 The Past Speaks to You, by Ann Livesay

No. 8 Common Insects of Illinois, by Gilbert Wright

Address all enquiries to the MUSEUM DIRECTOR, ILLINOIS STATE MUSEUM, Springfield, Illinois 
STATE OF ILLINOIS

Adlai E. Stevenson, Governor

DEPARTMENT OF REGISTRATION AND EDUCATION

C. Hobart Engle, Director
ILLINOIS S'TATE MUSEUM

Thorne DeUEl, Museum Director

\section{Illinois Mammals}

\section{Joday and Yesterday}

by

VIRGINIA S. EIFERT

$-*-$

SPRINGFIELD, ILLINOIS

First Printing-1943

Second Printing-1945

Third Printing-1947

Fourth Printing (revised) - 1951

Fif th Printing - 1952 


\section{FOR FURTHER READING}

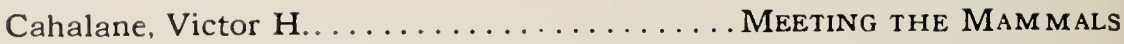
MacMillan Company, New York, 1943

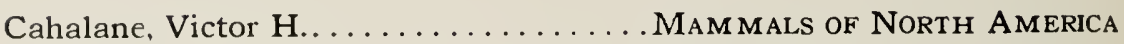
MacMillan Company, New York, 1947

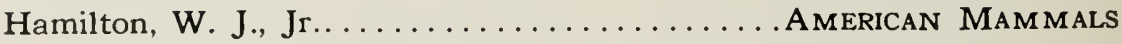
McGraw-Hill Book Company, New York, 1939

Hamilton, W. J., Jr............Mammals of Eastern United States Comstock Publishing Co., Ithaca, New York, 1943

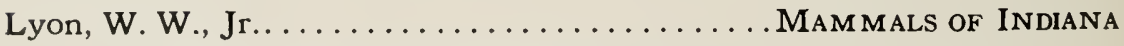
American Midland Naturalist, Vol. 17, No. 1, Notre Dame University, 1936

Cory, C. B....................mamals of Illinois and Wisconsin Chicago Museum of Natural History, Zoological Series, Vol. II, 1912 


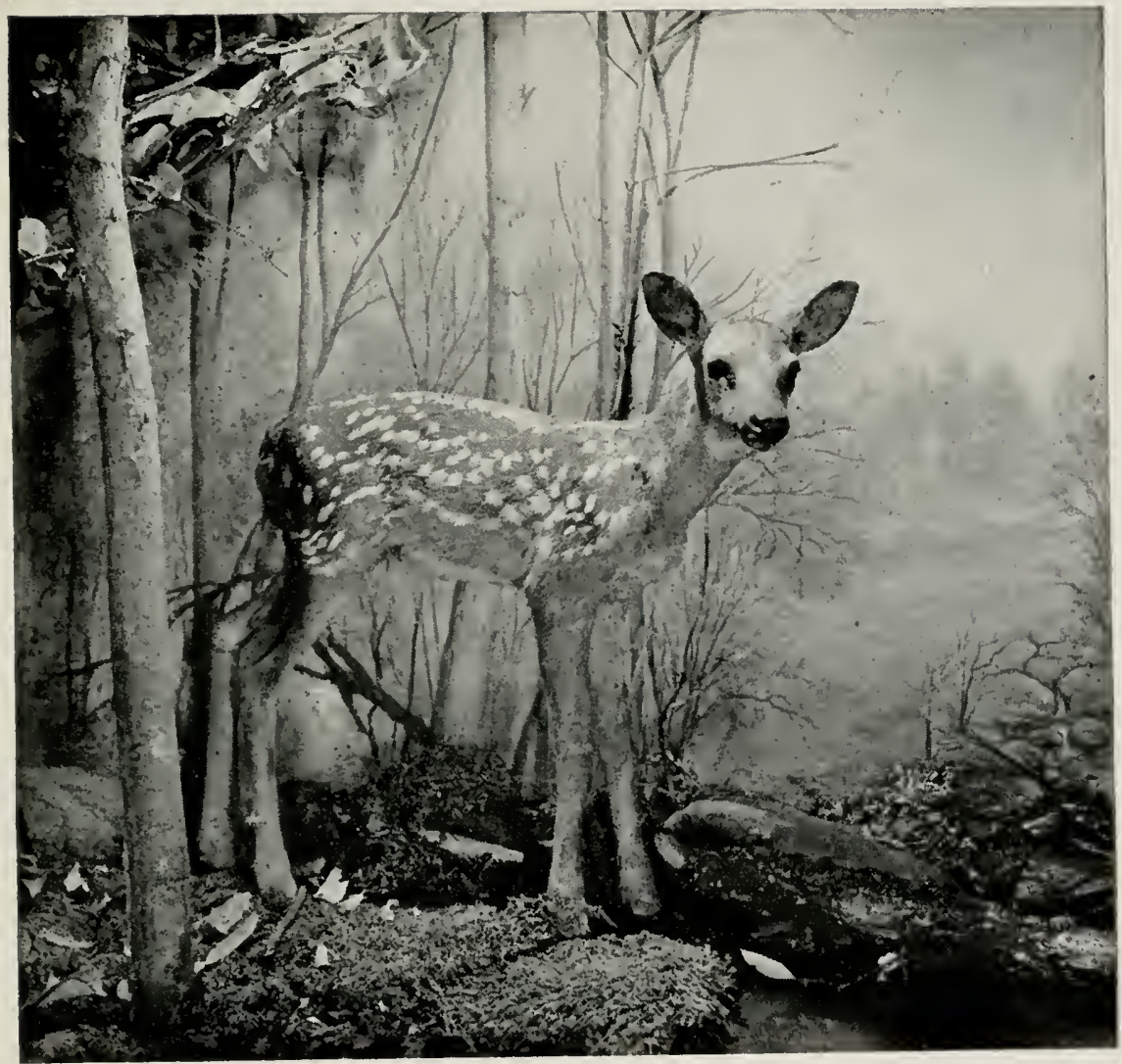

\section{THE ANIMALS IN THE MUSEUM}

"Is that little deer stuffed?" a small boy asked as he looked at the Museum's fawn.

To the lad, the means of preserving dead animals was to "stuff" then with sonething, but this method, once common, has largely been replaced by mounting. Museum methods use many materials to produce the appearance of life which now is essential in a mounted specimen. It is no longer a dead animal held back forcibly from decay; it is an animal brought skillfully to the alert appearance of life.

The usual method is to remove the skin and tan it carefully; the body is put into wet plaster which hardens to make a mold. Or else the flesh is removed from the bones and elay is built w around the articulated skeleton to take the place of flesh and muscles, and this form is cast in a mold. Inside the mold the preparator now packs wet paper and other materials until a complete shell of the animal is produced in papier mache. When dry, this is light in weight and retains the exact form and attitude of the living animal. Over this the tamned skin is painstakingly fitted, life-like eyes of glass are set in, eyes suitable for each kind of animal, perhaps whiskers are added, and the animal is ready to be placed on exhibition. It is so light in weight that it may be lifted with one hand. And it looks alive.

The purpose is not to fool the public, but to present as elosely as possible the appearance of living things; for the MIuseum is not a storehouse of the dead, but an illustrated. three-dimension picture book of life. 


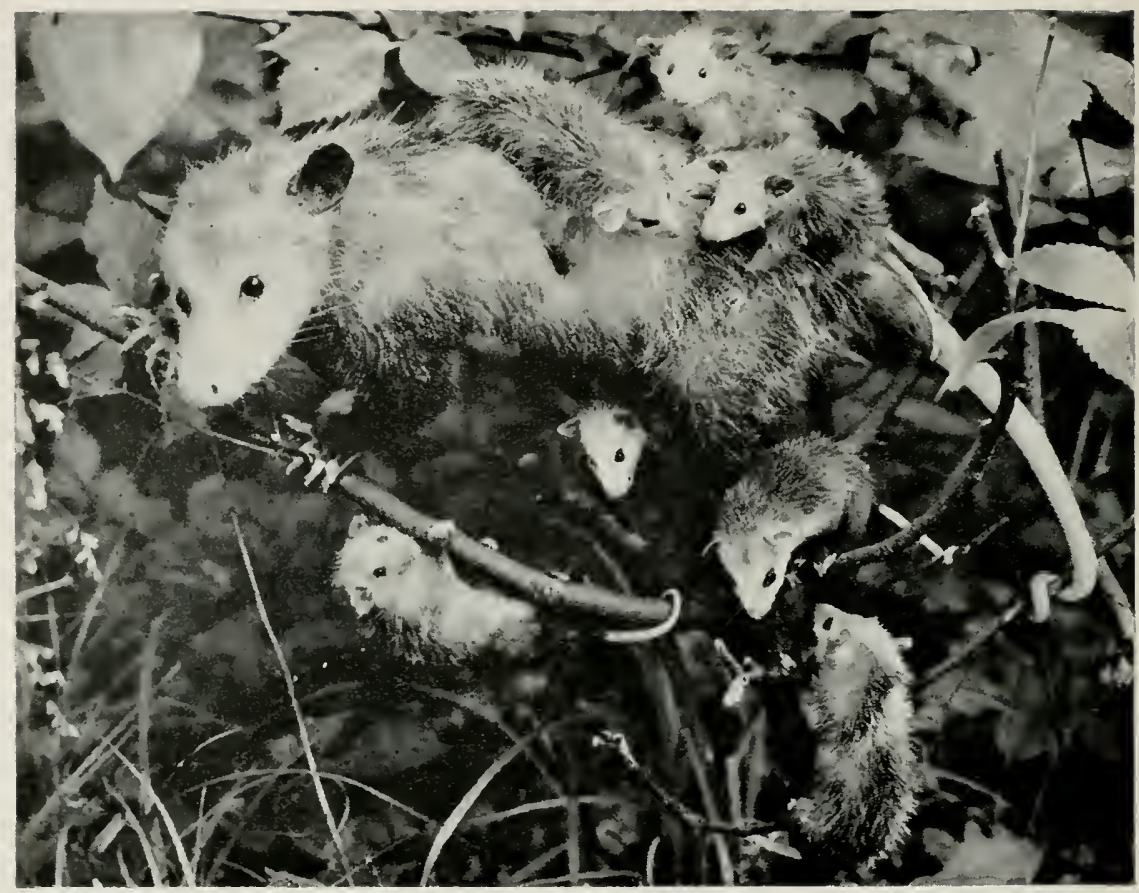

\section{THE STORY OF THE OPOSSUM}

(Didelphis virginiana)

Long ago when the world was younger, there were certain animals called marsmpials whose young were born very tiny and lived for a while in a kin pouch on the mother's hody, just as baby kangaroos do todar. As the ages passed. most of the marsupials vanished. yet some still live in the isolated rontinent of Anstralia and New Kealand, a few in Fouth and Central Anmerica, and one in North America. This is the grey opossum of the American wookls.

The oposmm": hrain has always been slow; it does not react rery funickly to emergencies. When frightened or in danger, the opossum falls orer in a fant and, with teeth bared, lies in a state much resembling death. This has been called, snecringly, "playing 'possum", meaning a state of pretended catalepsy. But now it is known that the opossum is highly nervons, and the shork of fright causes this state of fainting in which the body reactions and functions are slowed. But although the possum may have a bad state of nerves, it "im emerge from its illnes with surprising speed and escape to safer quarters.

An oposimm eats a number of raried things. from eggs and small chicks to bestles and dead-ripe persimmons, and when other food is searce it may become a scavenger. 'The opossmm hunches itself by the road where a chicken (1) animal has met death and. with green eves glowing weirdly, pulls at the shreels of thesh.

A nakerl. pinkish-grey prehensile tail enables the opossum to climb easily abont the trees, much as a monkey does. 'The feet with their grasping toes are strong and have opposable thumbs which leave ummistakable tracks in the mud. This then, is the opossum, a creature which has maintained its place in the world for millions of years without change, for opossums a million vears ago were virtually identical with those of today. 


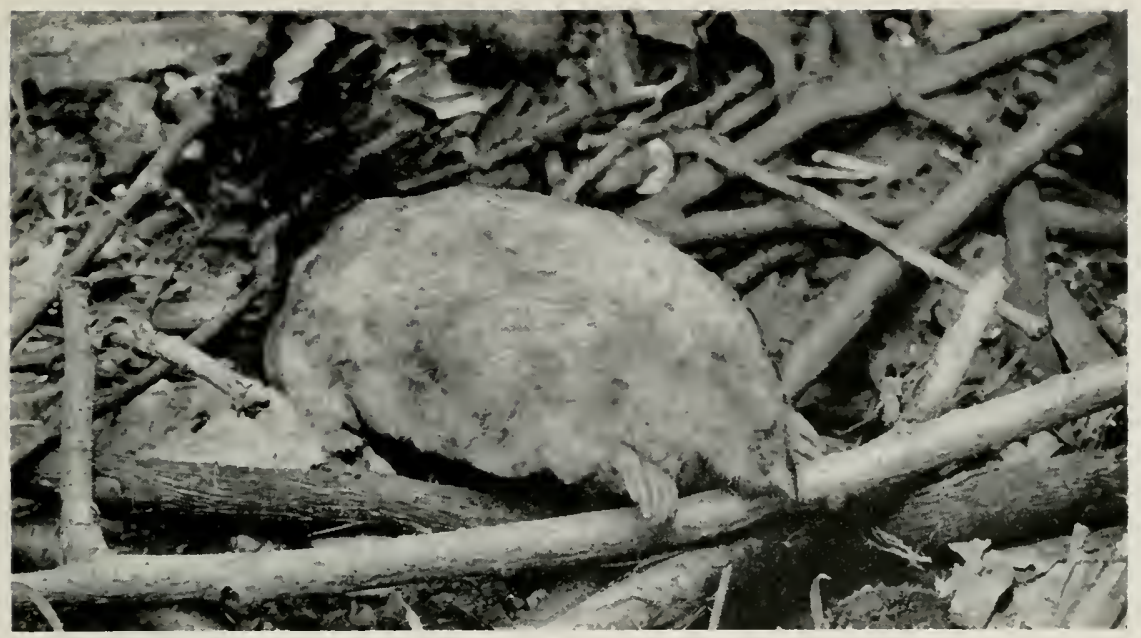

THE MOLE

(ścalopus゙ aquaticus)

A ridge of earth puthes up acrow the green lawn. Simmeone slouts, "There": that mole again!" and stamps on the solt carth. Instantly the burrowing ceases: somewhere underground a frightened, solt grey animal hurriedly turns around and suttles back along the burrow. There the creature pauses in black darkness and sniffs, as the keen whishers or vibrisale sense the presence of an earthworm which wriggles from the wall of the newly made burrow. The mole snaps at and seizes the worm. pulls, braces itself and pulls harder, until the worm, with a sulden letting go. pops out of the earth and is eaten. Still the earth trembles with the stamping of big human feet ans the mole hurries on its way along the tumel to the nest beneath a tree. Here in a wate. protected chamber the mole waits in the darkness until peace once more desends upon this small sertion of the earth.

Not until rather recently was the nest of a mole erer discorered, for it is well hidden under a tree or stmmp. The little moles stay here until they are almost grown. Then, like their parents, they thrust their long sumuts into the soft earth and with their flipper-like, strong-clawed fret they push, with a sort of swimmer's breast-stroke. throngh the soil in seatch of worms and insects. Doles are insect eaters. not regetarians, and their tumels into gardens are not for the purpose of eating hulbs or grass routs. Damage, however. often result: from the mole's vivits, and these are due to two factors. One is the fact that the meadow mice often come into the comenient burrows of the moles and nibble tulip and lily bulbs: the other is the undeniable fact that when air conveyed along the mole's tumnel reaches grass roots. the grass dies. The mole itself is a harmless, silent, furry grey creature which is seldom seen outside its tunnels in the earth. 


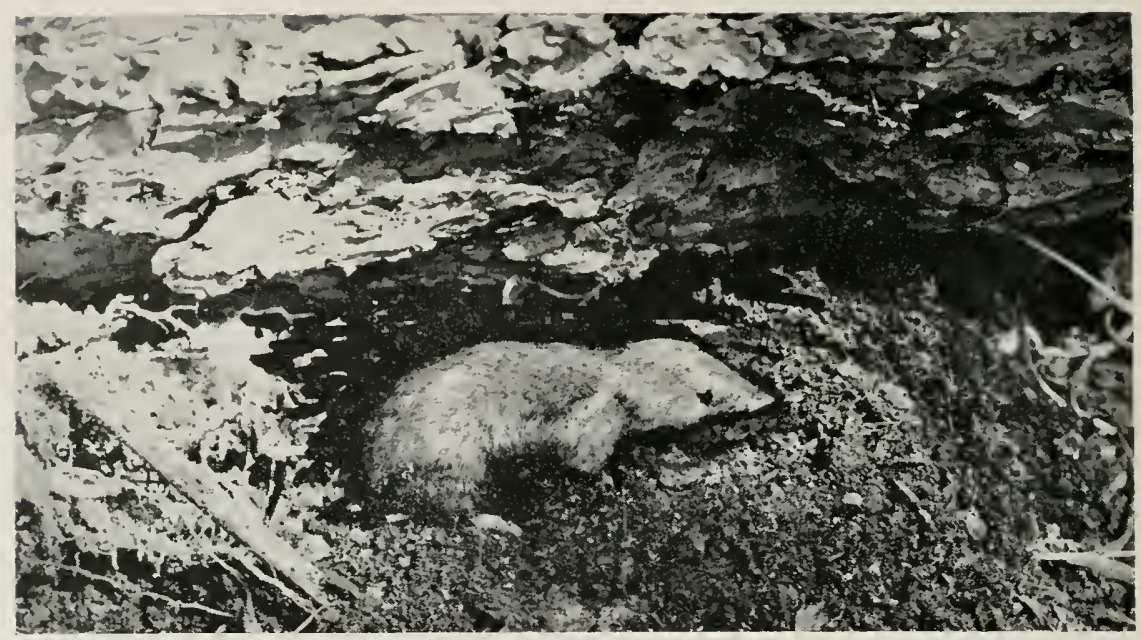

\section{THE SHREW}

(cryptotis parva)

()n a cold winter dar there are many tracks in the fresh snow. There are the honpungs of rabbits, the neat marks of spuirrels, the embroidery of junco track : and the punch work made by sipping wood mice. And there are certain other tiny track made with pupose and determination. They are small and move in an even pattern over the snow. They are shrew tracks. Eren and relentless, they move far off across the snow. around trees as if in pussuit of something which they would reach eventually without undue worry or hurr. Here is the hunting path of the shrew.

It is smallest of dmeriean mammals, smaller than a mouse, with a short tail, long snont and miniature paws, a grey-furred. lively mite. At night the tiny beast snifl's the wind to catch the warm seent of deer monse or sleeping hinel, and then stals orer the snow, not aimlessly, but with the silent desperation of hunger.

The shew is almost always humgry. It has sueh a highly stmug newous system and high rate of metabolism that it may die of fright or of simply going hungry for twonty-four hours. Throughont the rear the shew eat: many kinds ot fool-predominantly insects and snails and roung mice or romig hirds, even suall fish. It will devon the hodies of mice which are killed in traps and will walt all the romeng mice in a nest.

No wonder the hunting path is so deadly and mneroing in its purpose. The shrew. smallest of mammals, has an urent neel for food and a relentless urere to kill which is all out of proportion to the dimimutive size of its hodr. 


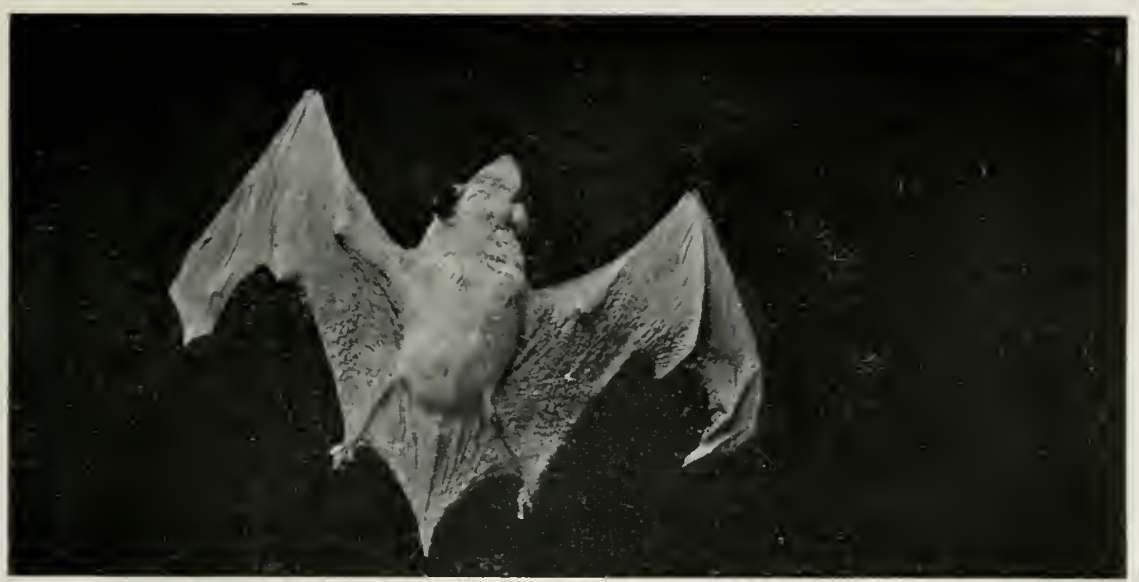

\section{LITTLE BROWN BAT}

(. lyolis lucifuyus.)

Grer the pond and through the half light of anly evening. the bats lluter on swift, merring wings. There are tiuy somels of mall tretle smapping on insects. the faint splueaks which are liat-talk. I $p$ and arounel and allay in the night. the hats are hunting for mostuitoes and other flying insects. bats ale so highly skilhed at insoct calching that sonecly any insect arapes the jursuit.

I bat is a flying mammal whose young-tiny furp packets of life(ding to the mother as she flics about at night. When thes are half grown and have hecome a heary loal, sometimes she "parks" them on a tree trunk while she hunts.

At night the hat i only a dark thiting thing. imbued with the quality of my-tery, witches. and superstition which has surromend it for ages. For renturies it was lonked mpon als the devil's own ugh rhilı. But close at hand. in daylight, the bat becomes an interesting little animal. The monselike hody is corored with soft brown fur. and the wings are thin skin -tretched across the winghones, which are like the clongated fingers of a land. The head has big round or pointed ears of great sensitivity: the snont is short. the month large and full of tiny shan teeth. The eves are keen, bright. little black beads, for a bat is not blind. Iot it does not depend upou eres to take it safoly through the night. Thr bat is a wonclerful mechanism of highly dolicate vibution recoption. It can fly merringly through tree twigs and interlacing wires and obstructions. without tonching one. This radar-like ability to detect obstacle before they are touched is the secret of that apparenty aimless flight at night when. nysterionsly. bats fly about and pick inserts out of the clatkness. 


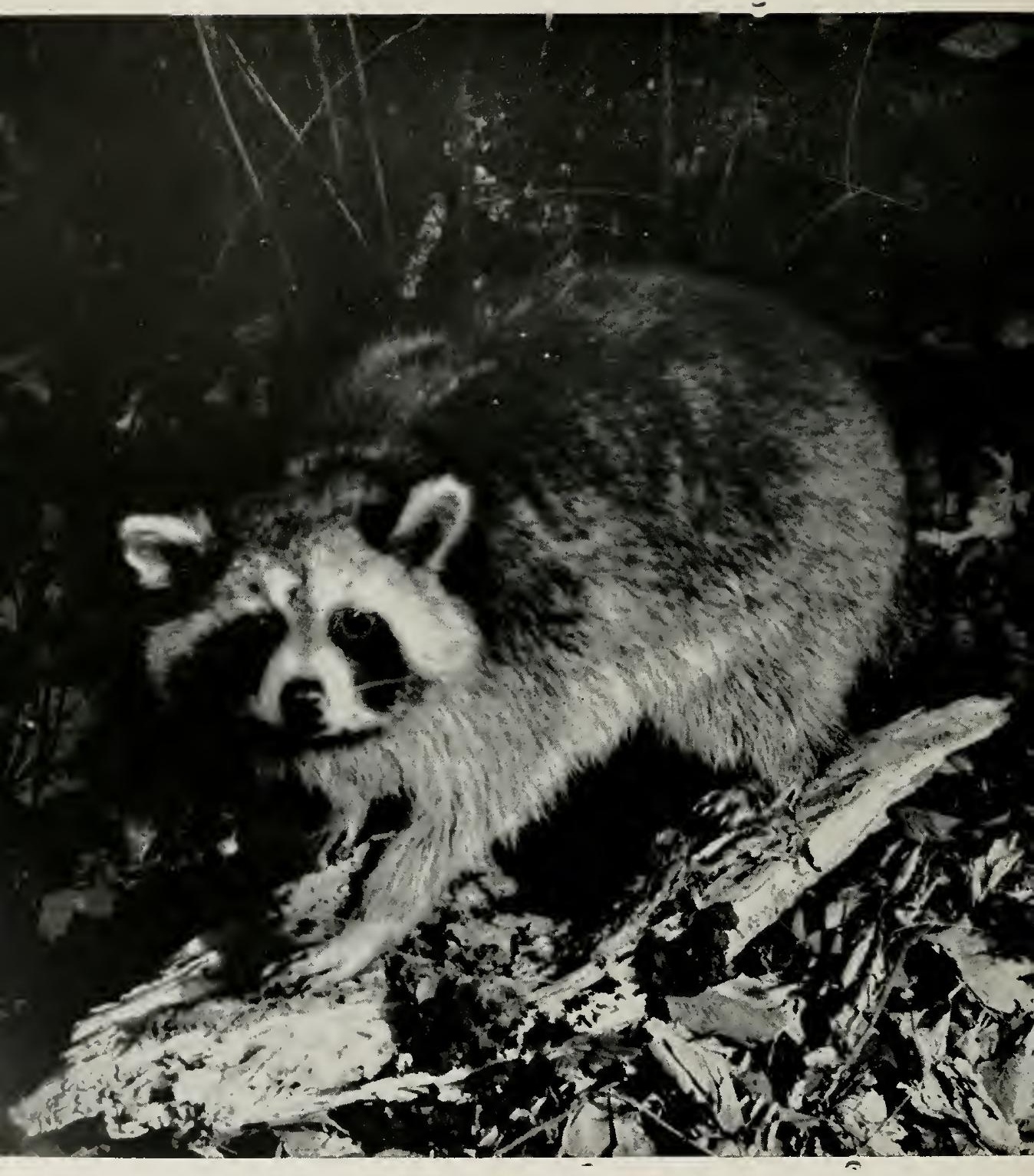

\section{THE RACCOON}

(Procyon lotor)

When dusk comes to the woods, the raceon starts out on a hunt for food. A fish or a frog from the pond. insects from an old log, a passing beetle, a dead bird, or sweet corn from the field-the raceon eats ahmost anything it finds. Raceoons are highly important in Illinois as fur-bearing animals; ther are common in woods, where the roung live in hollow trees until old enough to go out hunting for themselves. Raccoons are nocturnal animals which are not often seen, but the maze of footprints in soft mud along most of the watercourses of Illincis is proof of their abundance. 


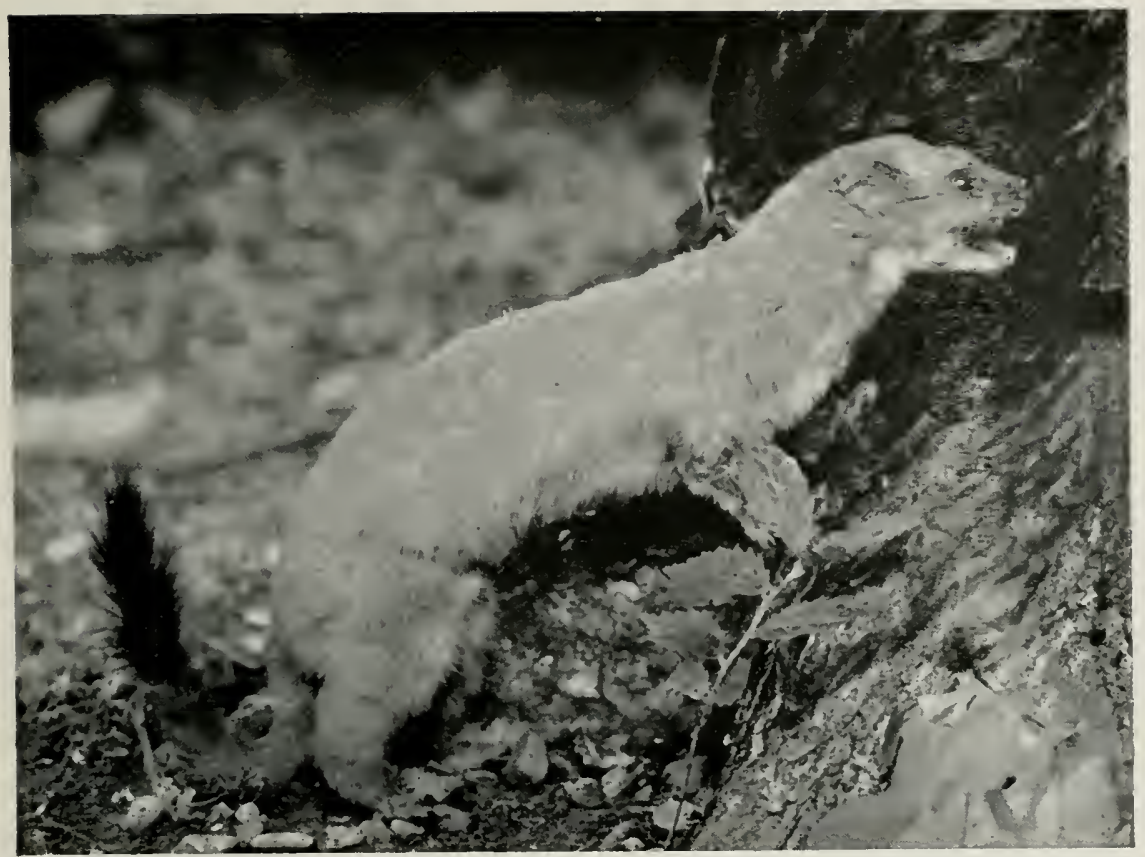

THE WEASEL

(. Mustela frenata)

The slim little brown creature lifted one paw and with bright, curious eyes watched the childeen plaving on the other bank of the creek. The weasel was motionless except fol the glinting of its eyes. 'The lithe body was poised in the silent. effortless grace of the very wild. It was there for no other reason than curiosity. Watched what the children were doing. was umafraid. Then, still without making a somme, the weasel put down its small paw and with an undulating motion of the slender body and long tail, lan off into the words.

This was the weasel in one of its milder moments, for normally it is not a peaceful ereature. It is a killer. and omer for omnce, is one of the fierest animals in Americis. 'The weisel is amivorous, but beyond the natural kill of food which is needed to sustain the slin boly are the binds, mice. chipmunks, (hickens. or other (reature which the weasel slays just beranse it likes the taste of hot blood and the tang of terrible fear which the victims know just before death strikes. Even thomgh the wasel is unpopular becanse of derels which, to the eye of man. serm eril. it is a suecessul animal in the ahility to live well and aceording to the mannes" of its kind.

In summer the weasel is dark brown with long. glistening outer hairs, and is white below. The tail is long and furr. with black near the tip. 'The northern weasels in the land of snow turn white in winter, all but the black tail-tip, but lllinois weasels usually tum a lighter brown. Winter and summer it roams the woods for food. 


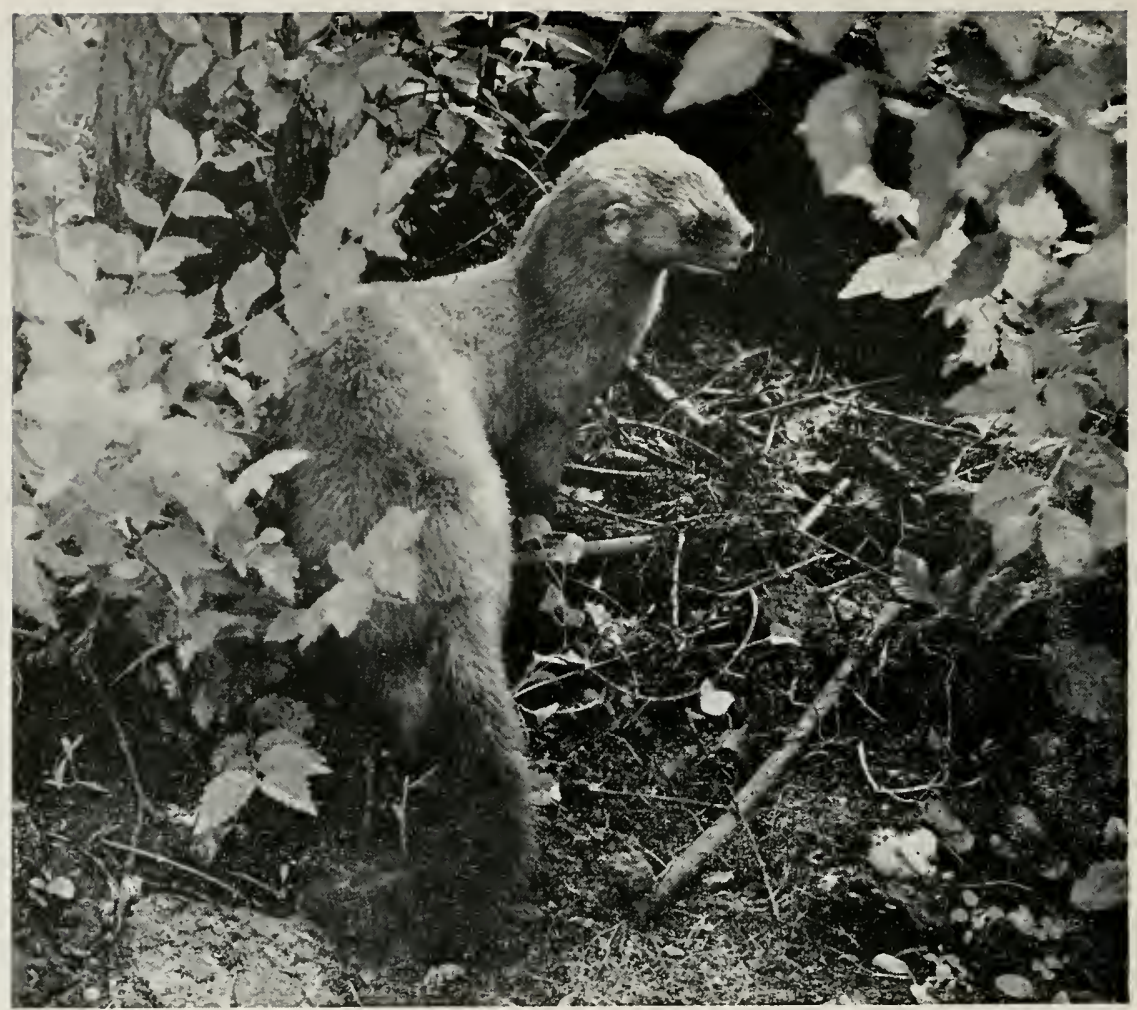

THE MINK

(Mustela rison)

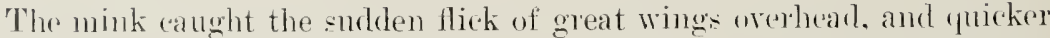
even than the owl that had dropped to clutch it, the mink dived without a splash into the stream. 'The owl hovered for a moment or two, then swooped upwal again and was gone. Meanwhile, the mink swam downstram, came up) for byeath and then went down again, and came out om the shore far away from the spot where it had dived. The dark brown fur looked black from the wotling, thomgh the water slid off quickly from the close, silky hair's. 'The mink shook itself. stood up suddenly on its hind legs to look about, then darted into the woods. 'The hunted now was hunter, the role the mink more lrepuently takes.

'The mink is a hunter in most of its waking moments: it sleeps only when it is too tired to continue hunting. 'Then. whererer it is, it curls mp and seeps a while. Tho mink will catch a fish, statk a frog. eatch a rabbit, follow a nuradow mous's streak up a tree to rob a bird's nest, or take a chicken neatly out of a famer"s pens. With short legs and long supple body, the mink maintains such specel that for pursuers wan catch it and hardly any of the jursted escatpe.

In lllinots the mink is most popular of all fur-bearers and is second in importance only to the muskiat. Each rear the proceeds from mink pelts hring half a million dollars to the fameds and trappers of Illinois. 


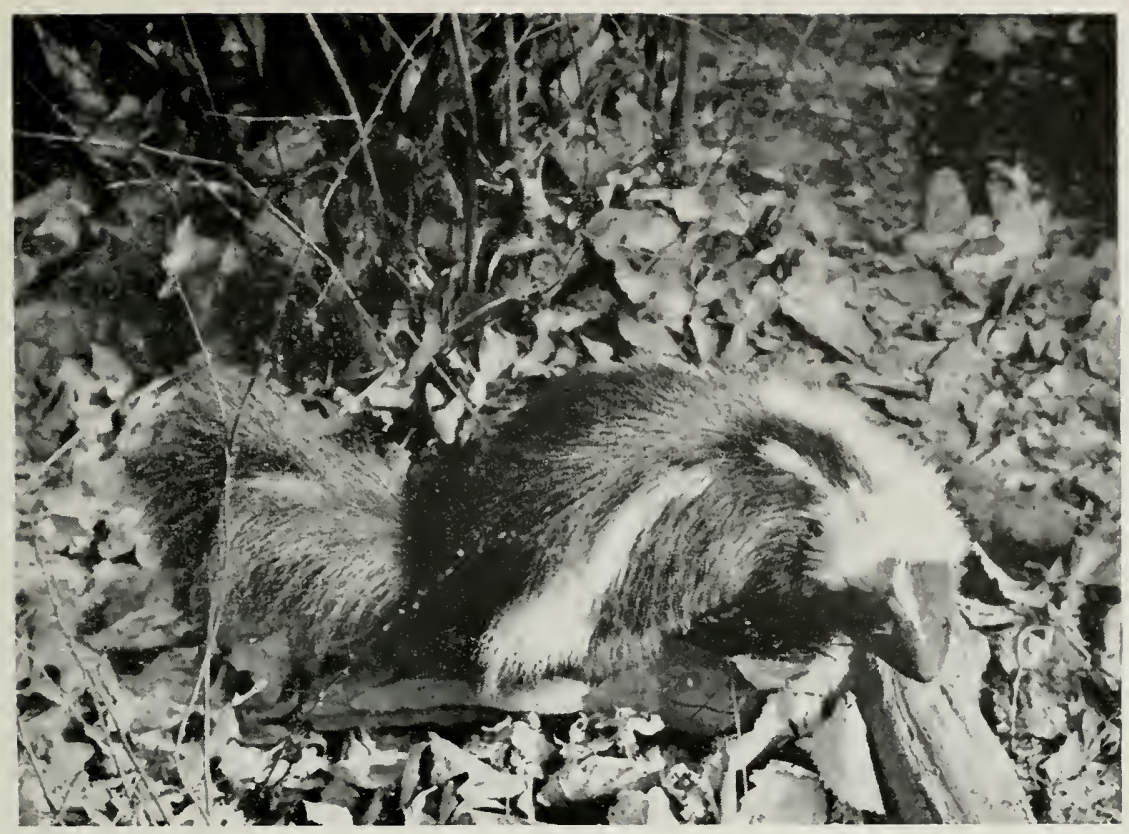

THE SKUNK

(Jephitis mephitis)

The skunk stepped proudly and a little pompousty down the woodlami path. The black and white tail blew a little in the spring hreeze. the heady black eves roved over the gromd. It was spring, and the skunk was humgry. A shiny brown beetle crawled across the path. The skmk pansed, pickert it mp, eracked the shell and ate every scralp. Then the skunk went on, white the new flowers of the wild crals apjle trees sent perfme into the air. and a pluebe eaught mospuitoes orer the trail.

Lsually the sumk is mikl-mamered and unaggressire if it is left alone. When someone approaches down the path, the skink will turn off into the bushes. A mother skunk and her young, lowerer, have the right of way and there are few ereatures. hmman or otherwise, who will dispute the path with her.

IThen threatened. the skunk pauses in dignity in the patls. There is a sudden lowering of the head. patting of the forepaits on the ground, and a sudden turn-abont as the plumy tail pises and a horrible sent engulfs that portion of the woods and all who happen to be in the way. The odor which the skmk throws from a sont gland under the tail is vile and choking. penetrates hair and clothing. and leare- a recollection which is hard to abliterate.

This is not the skunk" only means of protection. It is a goos fighter with teeth and claws when oration demands. The skmb. however. is known by the silent punishment of its scent and is forever mathed as the Animal with the sinell. 


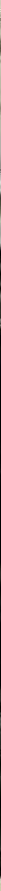

THE FOXES

(Tulpes fulva)

Long ago an old $\log$ fell over on the slope above the pasture. Now there is a dark spot beneath it - a hole. A yellow-brown area on top of the log, a flick of motion, and suddenly into focus comes a fox with chin on paws, watching. On the packed clay by the hole three young fores are sleeping. It is a placid. sun-wamed scene, yuiet with that mid-afternoon hush which even silences the catbind in the thicket and sends a sleepy drone from humblebees in the rlover.

There is a flash of bown in the weeds as a sleek body slips into the faw naw thicket. There is a short. sharp bark and, at the sound, the for on the log stands ur). The little cubs scramble to their fect. wobble, topple over, snap) and snarl in mock ferocity: each tries to be the first to reach the vixen as she comes to the den and drops a bird for them to fight over. 'The feathers 1 y.

Fox families like this one are becoming more fommon in Illinois. Tuder the very noses of men, the foxes hunt and rear their roung, rear after year, and instead of falling beneath mans oppression, they have hecome inore keen, more alert. more "foxy" in eluding the dangers which civilization has put in their path, perhaps more so than the old-tine foxes of the wildernes:

The red fox, pictured here, is the more common of the two fores found in Illinois. The other, the grey fox, is a little larger and not so common. 


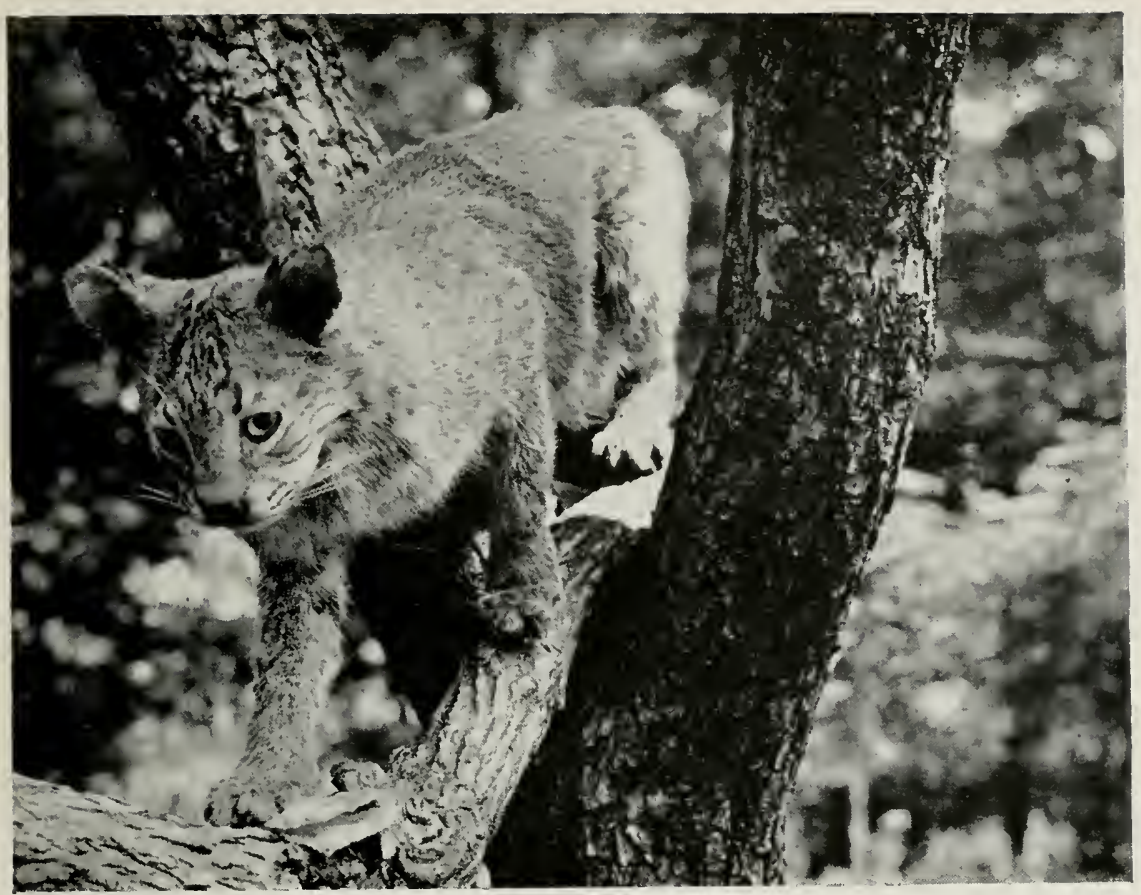

\section{BOBCAT}

\section{(Lyn.x rufus)}

It was dusk in the great swamp. 'The chmek-will:-widow called, and the mosquitues made an mudertone of humming which filled the forrst. 'The swanp olimmered silkenly where the angular erpresses and tupelos stood tall and black. The noises lose and foll-the groaning and clicking of frogs, the squawk of a night heron, the querulous ery of a racoon. the far-otf bark of an owl, a sudden crashing in the underbmsh. And then there ame that call. It was a wild seream, a coughing (ry, so fieres, so motamed, thit cren the cluck-will:-widow ceased on a half note. and momentarily there was pulsating silence as the coatures pansed. puivering. and listened. 'The bolucat was at its hunting.

fiomewhere among the canes there cromched a brown, furry animal, al short-tailed ant three feet long. It came on huge sult feet through the devious paths of the cane into the more open places of the forest. through the ferns. snifting. hunting. A wood momse, nervously mable to be still, skipped over the path and the big eat pouneed, canght it, wolried it a while. ate it. Again came that heart-stopping yow. It was the somm of the almont forgotten primeval wilderness which still lived in the swamp.

The bobeat is still to he found sometimes in Illinois. but althomeh it is not too mueh distubed he civilization, it still prefors the deep swamps and forest. It lives in southern Illinos where the hills are hiogle and the evpress swanps remote, and occasionally in river forests thromghent the state. Becanse the bobcat is so secretive and soldom anes out in disylight. it often may go monspected. Dmring the day it serps in a hollow tree ol on a ledge of rock and comes ont for its hunting in the pleasant loums of dusk. 


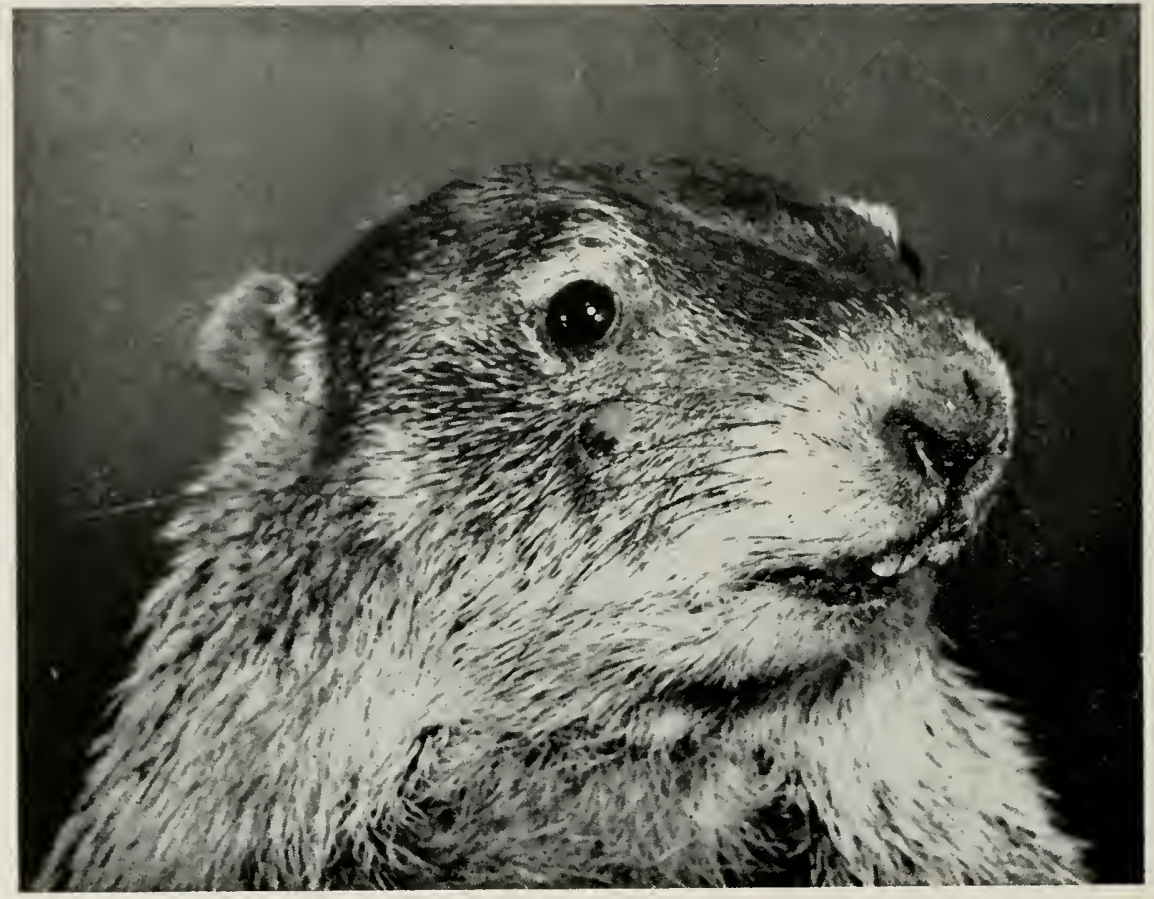

\section{THE WOODCHUCK OR GROUND HOG}

\section{(Mamota monax)}

A woodehuck, rich brown fur glistening in the sun, furry tail lolloping behind, runs along a eountry road. Here is one of the largest of Illinois rodents, a wild creature which has adapted its wildness to the nearness of men. It is constantly on the alert, whether rumning or sitting upright to riew the scene: for the farmer, considering the wcodchuck a pest, is alway ready to exterminate it.

The woodchuck is heavy-set and furry and appears larger than it really is. with sleek head and close-held ears, and big ineisor teeth whieh, as in all rodents, mart the woodchnck a gnawer. The fiont feet have strong claws for digging because the woodehuck lives in deep underground burrows which are lug with plenty of extra entranees and exits. Here in spring the young are born, and by late smmmer there are plenty of half-grown young chmeks ont in the fields nibbling clover with their parents.

In midsummer, woodchucks appear to aestivate. This is a summer form of hibernation which shows the living processes as the animal slumbers in its burrow. By autumn, however, the woodchucks are again alert and after eating for many weeks, have grown very fat. As cool weather approaches and frost sparkles on the elover leaves. the woodchucks again beeome drowsy and slow. And to they go down into their underground tumels for the last time in the year. curl into a ball, and so to sleep. Their shumber is so deep that it is almost like death. It is a slowing of pulse, heart-beat, and breathing, with body temperature in the forties. The woodchncks in their burrows are insencib!e to whet is going on above ground until spring comes. Then they roturn to conscionsmess, blink and stretch, and come creeping ont to hunt a goorl bite of young. sueculent clover leaves. 


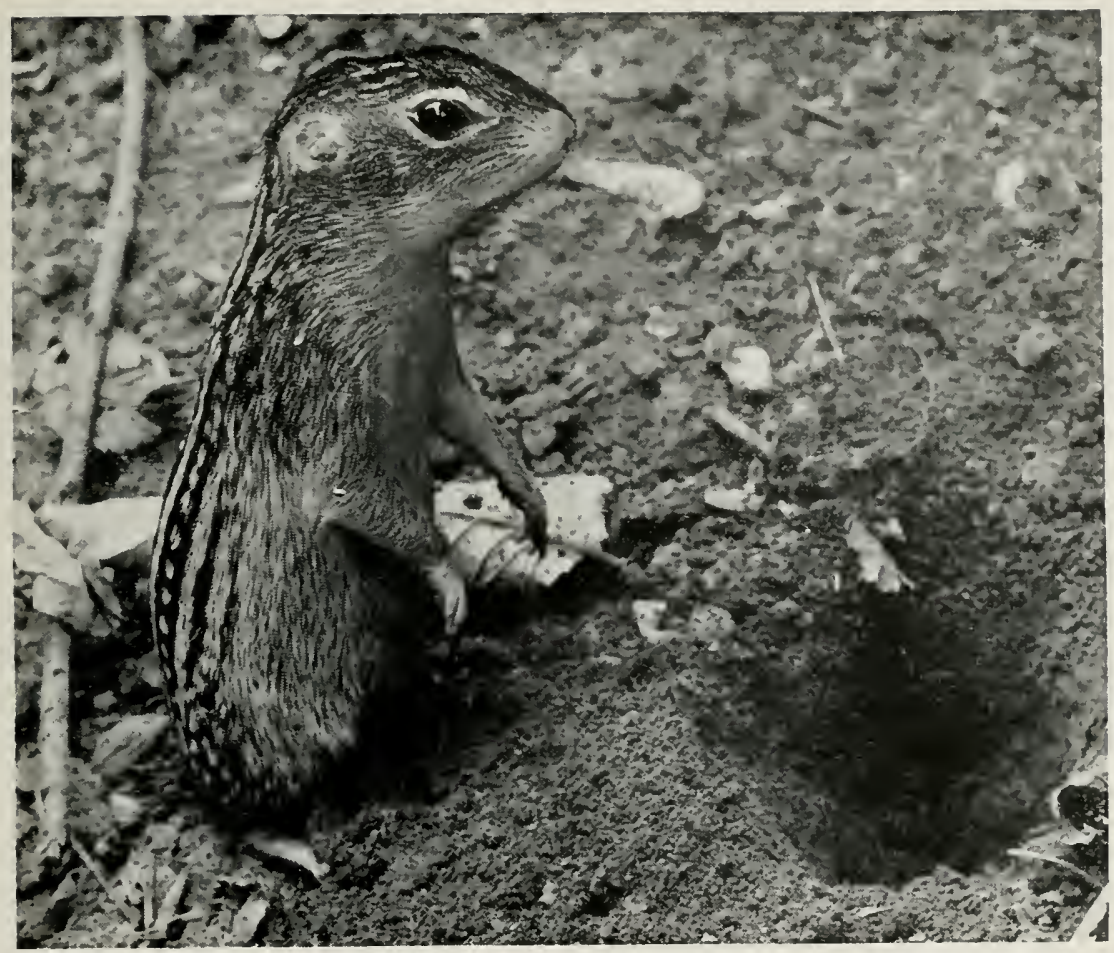

\section{THIRTEEN-LINED GROUND SQUIRREL}

\section{(citellus: tridecemlinealus)}

In open country, in parks, roadsides. cemeteriss, and on golf contres there lives the thirteen-lined ground spuirrel. It is not a gopher, as it is uften called. but is a true squirrel, a spermophile. which prefers to live in holes in the ground instead of in trees.

The thirteen-lined ground squirrel is a small, sind-colored. sleekbacked little squirrel with sparse tail, big eyes set rather high in its heal, and thirteen stripes down the back. The stripes. mnlike the firr smooth, plain stripes down the chipmunk's back. are broken into little scpures.

The sround squirrel. secure in the smmy grastand, perhaps is most often seen in open, mowed park land, golf courses. and most commonly of all in cemeteries. On the golf course. the grommes squinel's holes often conflict with the proper holes of the game; many a time a golf ball has rolled into a spuirrel's bnrmw and cammot be retrieved. Meam while the owner of the burrow sits bolt mpright like a tent picket. jerk- an abhreviated tail, presses its forepaws against a heaving bosom. and utters a piereing. shrill whistle, a high-pitched barking which continues for many minntes.

Throughout the summer the gromnd symirrels lum albout through the grass, eat puantities of seeds, and, as winter approaches, they spend more and more time in their mderground dens. As cool nights lay frost on the green things, the gromnd squirrels come out only briefly and at last they go to sleep for the winter. Far underground, helow the frost line. they lie curled up in a state apploaching, ret not quite touching death. and there they stay and sleep until spring. 


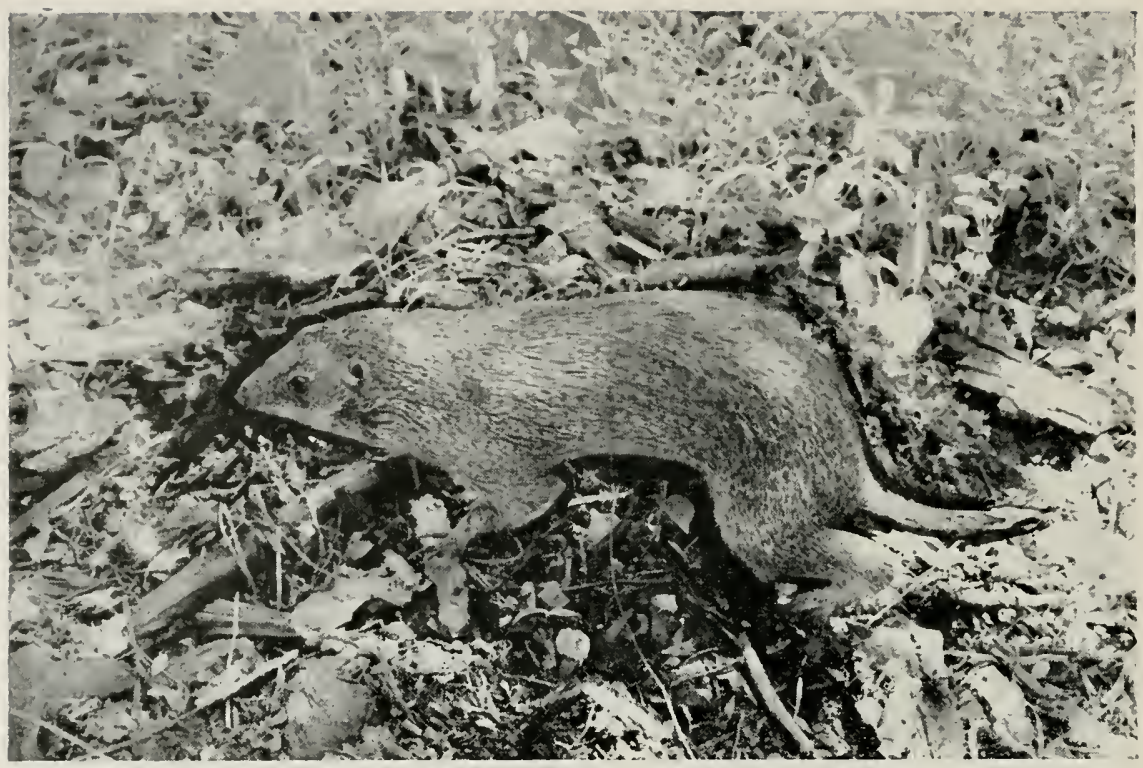

\section{FRANKLIN'S GROUND SQUIRREL}

\section{(Citellus franklinii)}

Ground syuirrels are spermophiles, and spermophiles are seed-eaters: most of them live in the open places of this continent. 'The western states are full of them-the little antelope ground squirrels of the desert, the flicker-tails of the Dakota plains. the golden-mantled groumd squirrels in the Rockies and the Sierras-spermophiles in rocks. grass, and anong sage and cacti.

Ground squirrels seem to be in a comstant state of fear and are streamlined as if for the quickest possible escape. 'They burrow in the ground, make their nests therr. store food there, and find shelter underground from the smap of a coyotr, the swoop of a hawk, the soft wing-beats of an owl. Spemophiles live in some of the grandest country in America. 'They know how the desert feels in a storm at midnight, how broad are the plains with a vast sky over them, how sung the momntains are. where in their hugeness even a spermophile may find a hole for shelter.

() ne of the spermophiles typical of the plains and the middle west as far east as Indiand. is the long. lean, grey Franklin's ground spuirrel of the roadsides. It is abont twice the size of the little thirteen-striped spermophile of the golf courses, and has a rather long. sparsely furred tail which streams behind when the squirlel decides on a dash across the road. Or, sometimes, the passerby along the prairie roadside may see a arey ground squirpel sitting upon its haunches, paws pressed to a white bosom, observing the colnfields and the sumshine, and keeping an eve on the lawk soaring ner the next field. 


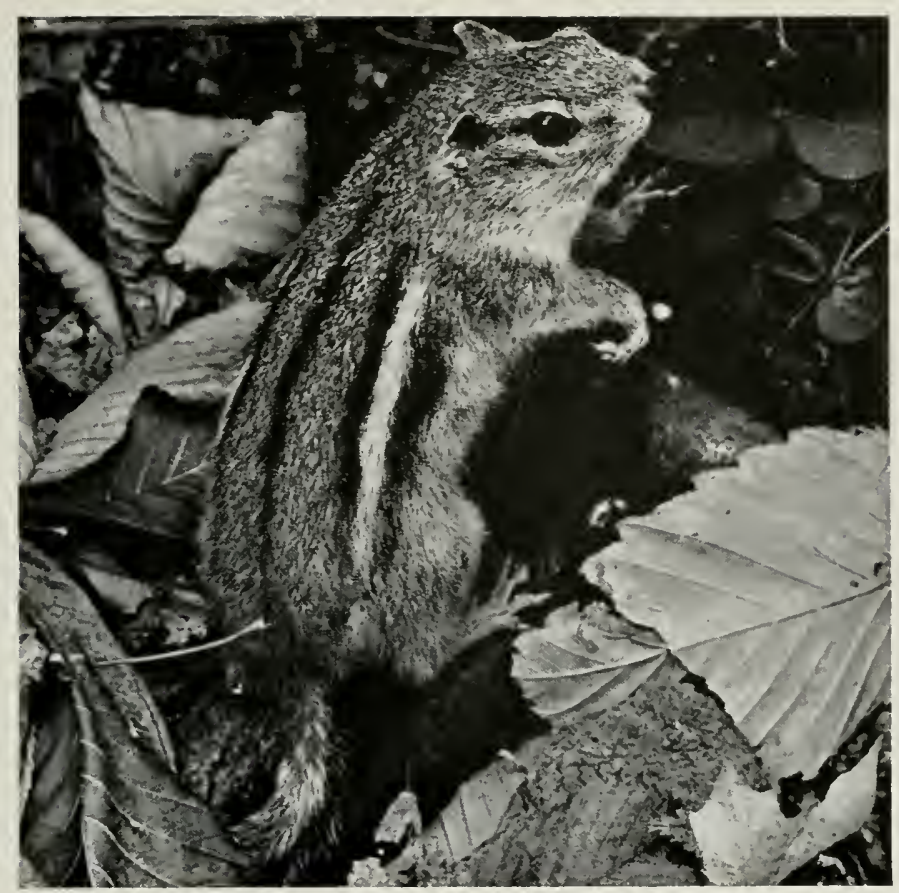

\section{THE CHIPMUNKS}

\section{( Tamiss striatus)}

Around tree trunks, over humpy roots, through the crackling dryness of antumn leaves, there goes the bustling sound of little feet. The chipmunks are working hard and the woods seem full of small, sompering. mysterious little noises. There goes another-and a phump brown rhipmunk, tail upflung. cheeks stuffed with seeds. dashes oft to a hole in the ground.

The chipmunk spends most of its time in a seareh for food. or in digging home burrows in rocky places or under tree roots. Town in one of these complicated underground hallways ar sleeping dens and foot-storage chambers. Hard bassmood seeds are neatly halved and the meat eaten: hazel muts are hastily monopolized and stored away: the sweet white rak acorns are often garnered. and so are the sects of panie grass, wild plum. wild (rab. and apple. Even mushoums are eaten. And when a eamper drops a prune seed along the trail. the first chipmunk on the scene hurriedly stufis the prize into a cheek pocket and races off to dine in solitule. The dehris of picnic spots is closely cxamined. and small edihles are carried away in furry chipmunk cheeks or prudently eaten on the spot.

"The dhipmunk probably feets safest on the ground. especially when one of the entrances to the home hurlow is well within rach. However. in time of extreme danger when the hole is too far away, a chipmunk will mun up a tree and from a pereh of vantage will scold the intruder below. A chipmunk has a most suprising voice for one so small amol appalently so meek. With wren-like violence, a loud. irritating complaint is shrilled from an angry chipmunk-perhaps one who has been anmoged at his work on a stone-hard prune seed. 


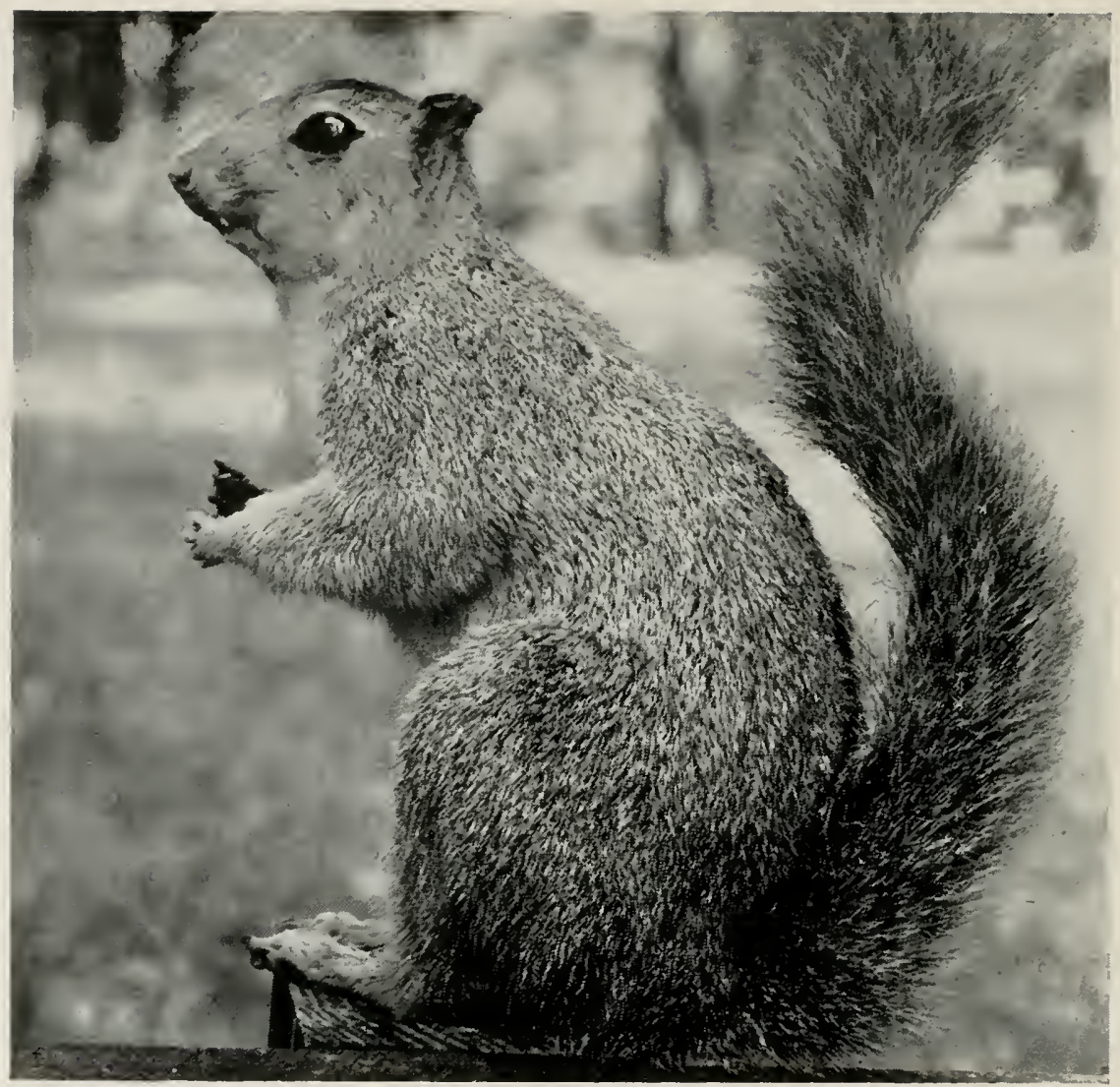

FOX SQUIRREL AND GRAY SQUIRREL

(Ściurus niger and ściurus carolinensis)

Gray squirrels and fox spuirels are residents of Illinois, but they are suldom found living together in the same woods. When that oceurs, the gray squirel probably has imvaded the territory of the fox and has come out the victor in the inevitable argments and fights which ensue. Both have very similar habits: both will take egess from a bird's nest. both on oceasion will devour young birds, hoth will hicle cpuantities of muts each autumn that are never found again. Sipuirrels-the rusty-brown for squirrel. and the snaller, delicately colored gray squirrel-are rery much at home on the ground, but they are essentially tree dwellers and run for a tree when clanger approaches. Once in a treetop. the squirrel's technique varies from scolding in a loud voice, tossing nutshells or bits of lark on to the heads of passershy, or galloping at a great rate of speed through the treetops via the twig bridges which commect the trees of the woods.

In winter the squirrel. with tail curled over nose. likes to put in long hours of sleep in a big bulky nest of leaves in a tree. but the squirrels do not hibernate. Sometimes the leaves blow out and make eracks through which coll winds push, and then the syuirrel hastily dashes out to bite off a mouthful of shingle oak leaves to patch the hole. 


\section{FLYING SQUIRREL}

\section{(Glaucomys volans)}

Down from the maple tree at twilight a shadow flits and is gone into the soft darkness. There is no sound and no flutter of wings: simply, a shadow comes down and vanishes, and that is all. Evening after evening it happens during the cool springtime.

But one May morning there is a fussing and complaining and twitching in the maple tree where the old wren house hangs. The wrens are back and they are enormously indignant. Something lias gnawed the opening of the wren box until it is big enough to admit a robin-if a robin ever would enter a wren house-and it is full of leaves and sticks.

suddenly from the overly full nest a grey creature sails out into the morning sunshine, lands on a tree trumk and clings there. It is a flying squirrel. a large-eved. gentle creature. grey-brown above and neatly white below. with flanges of furry skin which help the squirrel glide down-not fly-when it launches itselt into the air. The flying squirrels have taken orer the wen's nest, and there is nothing to do about it now except to let them star. for inside the nest four soft haby flying spuirrels are curled in the bits of fur and leares. It has been the aduit flying squirrels which at dusk sailed without a sound out of their tree and have gone unseen about their nightly hunt for food-for nuts, seeds. fruit. insects.

Flying squilrels often are more common than one may suspect, for the nocturnal habits put them in the category of thing seldom seen. Many times they fund their way into atties and in crannies under eares. ol eren enter houses. Where they make mystelious tapping and rmming noises which oftentimes upset the nervous or superstitims inhahitant s of the house. 


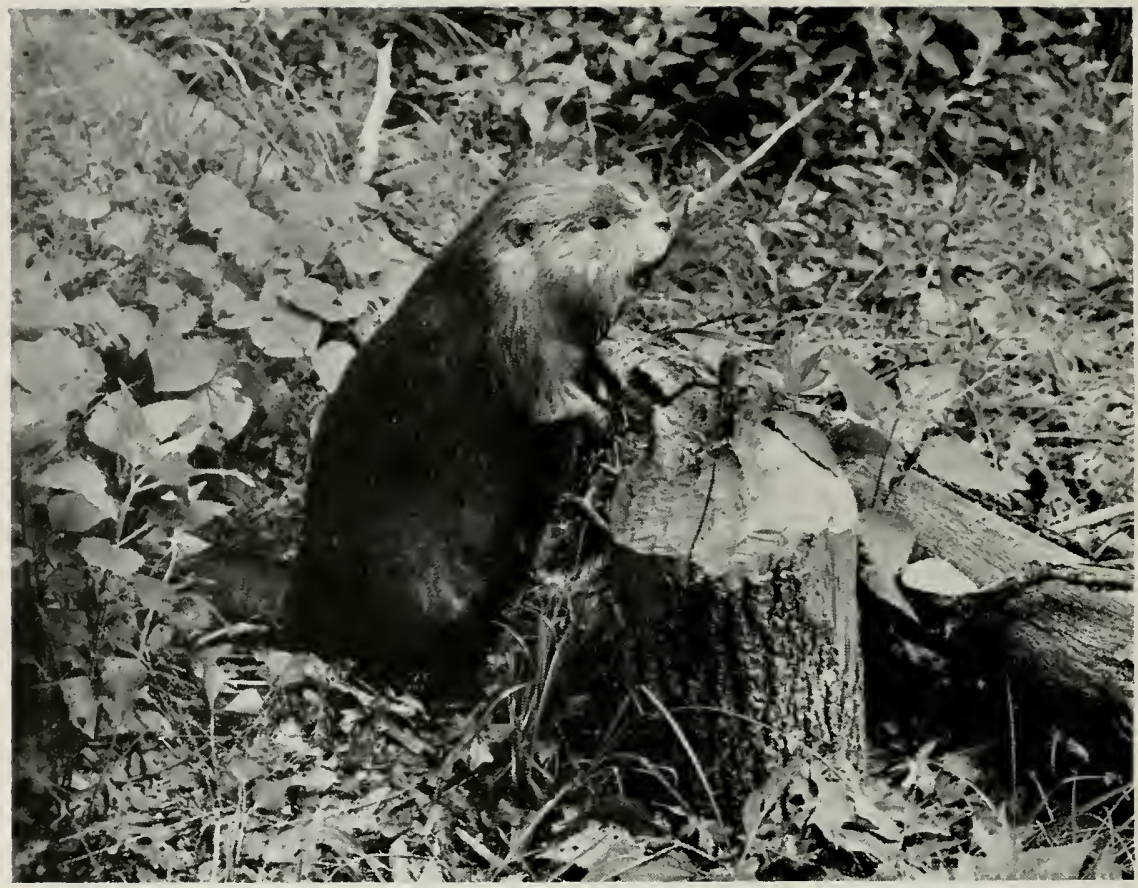

THE STORY OF THE BEAVERS

(Castor canadensis)

A long time ago in Illinois, beavers once lived their peaceful community lives. Then they became extinct in the state, for they could not withstand the approach of a civilization which for centuries has demanded beaver furs. It was the Hudson's Bay Company long ago which sent trappers into the unexplored continent to take beavers or barter with the Indians for the valuable pelts. The search for beaver opened America to later settlement, opened the Oregon country, the Great Lakes, the Canadian wilderness. and the Wisconsin, Michigan, upper Illinois, and Minnesota country.

By and by the remaining beavers were largely gone from their old haunts: those which remained lived in quieter, more remote wildemess places where they could have peace. Now with legislative protection the beaver in many places is becoming more abundant. It has been introduced into southern Illinois where it has been successful.

In spring a pair of roung beavers finds a small pleasant stream and builds a strong dam across it to make a pond. They choose slender roung aspens and cottonwoods and willows. and gnaw completely around the trunk as high as ther can reach, until each tree falls. 'Then the branches are clipped off with those sharp orange incisor teeth, and the trunk is dragged to the stream and added to the dam. When it is finished, a quiet little pond forms back of it.

The beavers cut more trees to build a house. This is a great pile of sticks and mud and sod, all thatehed and matted together. with rooms inside where the beavers rear their young and spend much of the winter weather. 


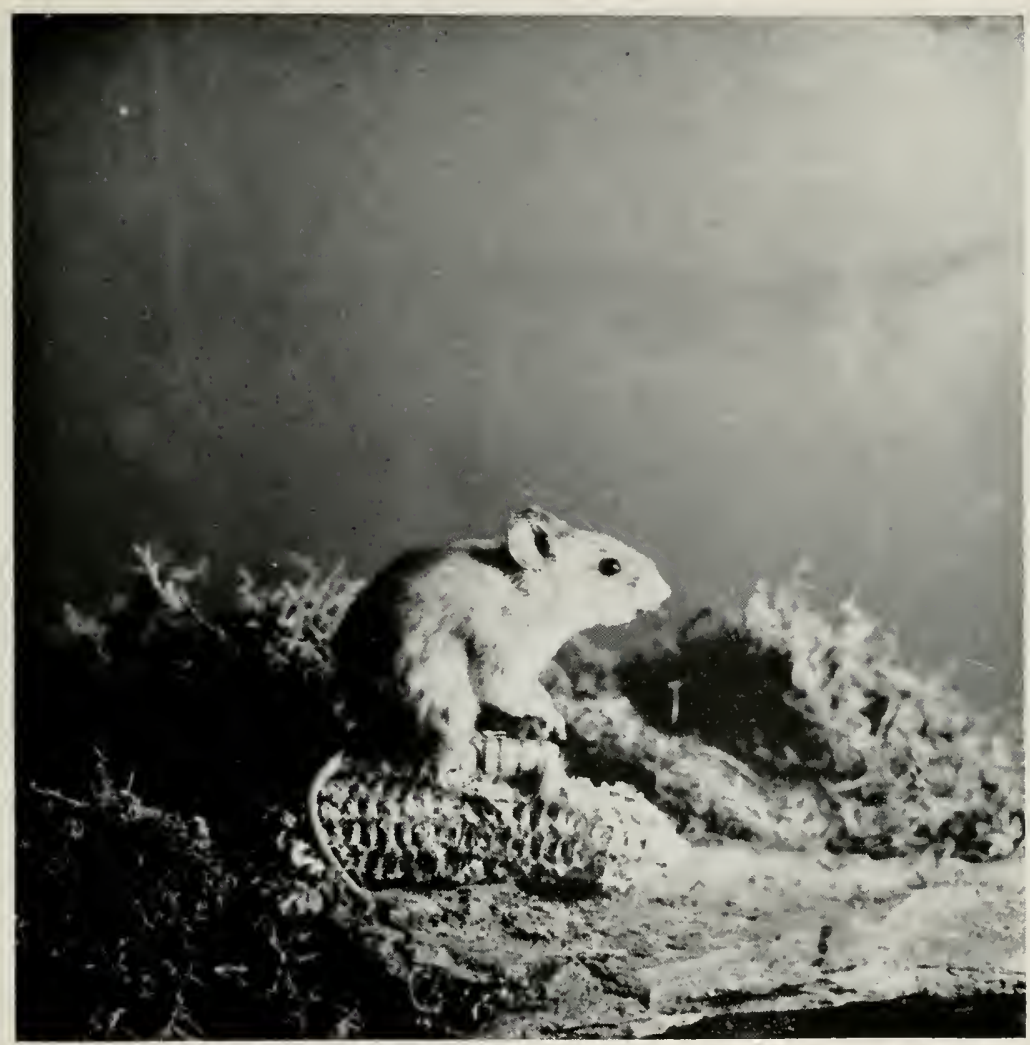

\section{DEER MOUSE}

\section{(Peromyscus maniculatus)}

A wide-awake little animal of the winter works is the derer momesmall, plump, grey-brown above, with clean white feet and underparts and a long. agile tail. "The eyes are black and large, the ears soft and pink, the whiskers long and expressive. Instead of preferring hmman habitation, as some mice do, the deer mouse puts a roof on a brown thrasher's old nest. fills the hollow inside with willow silk and plant filers. and sometimes adds a few feathers or bits of sheep's wool that have tangled on the fences or bushes nearby. A small opening is made for a door on one sicle of the nest.

The deer monse, however, is really an animal of the gromol, and here it hunts for food. There are stores of food here and there for a lumgry monse. It knows where there are more of the tiny hard haswowed seeds which it cracked and ate under a log last fall. It knows where there are hickory muts which, hard as they are, ean be gnawed and the kernels antem. And on winter nights when the moon sends long shafts of white light orer the ragged stalks in the nearby comfield. the deer monse latres its nest and goes in long leaps to the field. Tp a shrivelled cornstalk-on to a yellow nubbin-a long look around. Then the mouse sits on its white toes and snaws away the bleathed old husks and nibbles the hard, yellow kemels. The small sounds of gnawing are loud in the puiet winter night.

Next day there are footprints scattered over the smow: there are tootl marks on the left-over corn, and in the winter woods dese by, a wam mouse is sleeping in a thrasher's remodelled nest. 


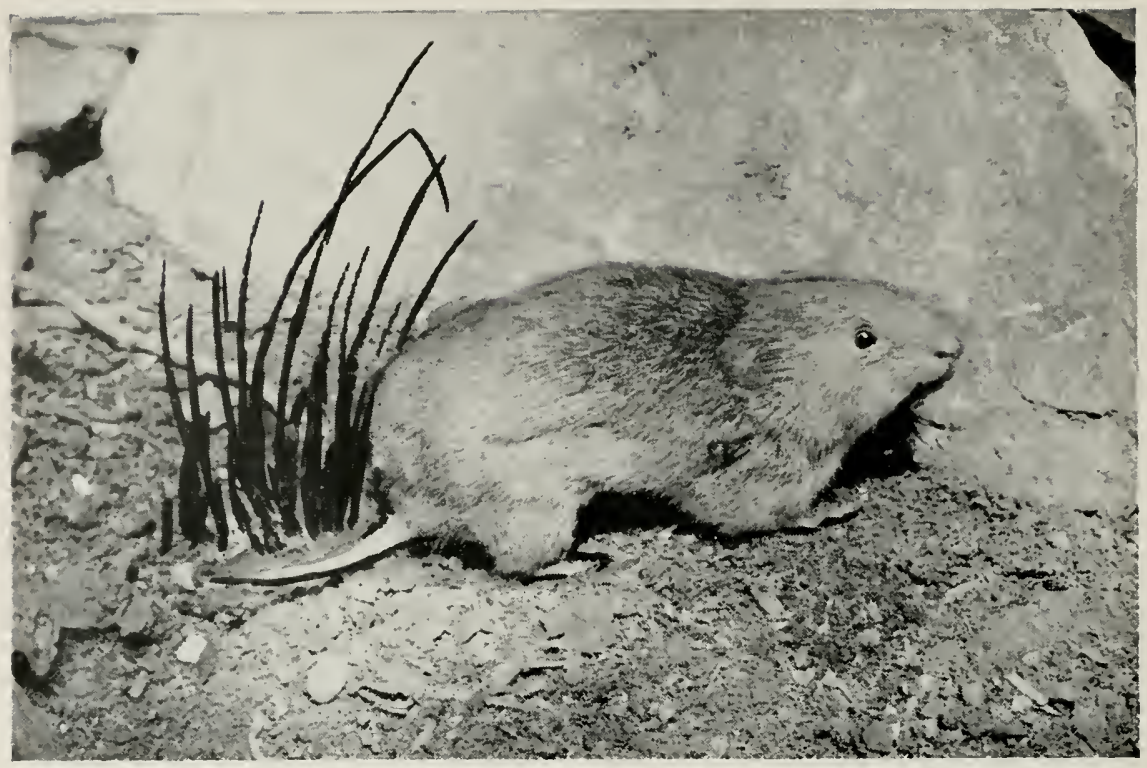

\section{MEADOW MOUSE}

\section{(Microtus pennsyluanicus)}

Down in the grass on a summer afternoon there is a most surprising view of things. In the tangle of grass blades and old dead stalks and stems there are hittle lanes and runwars. At first they might seem aceidentalthe mere natural growth of the grass, the whims of plants. But they are not aimless. Here is solid planning and engineering. for these are the roadmays of the meadow mice.

Ever since the grass grew, the little brown mice. short-tailed and lomnd-borlied. Insily clipped off the grass in the sod. Ther made a little lane that was hig enough for mice to travel comfortahly back and forth about their business withont having to renture out into an unprotected world full of hungry enemies. For long distanees from the hurrow and its nest. out in twistings and windings that lead far into the grasses or to the srain fields, theso neatly ent and maintained roadwars show where the wild mire, day and night, run alout in privacr. No twig is allowed to obstruct a lanc. fol one day it may mean life or death when a monse comes stipping 31 palpitating fright to safety. There are too many enemies of mice for them to neglect theip one aveniue of escape, but when a grass fire cleans off the meadow, all the network of lanes is exposed to view. The lanes are paved with mone footprints, stamped down by tiny paws.

The meadow mice perhaps are one of the commonest of Illinois mammals, ret they are seldom seen berause of the efficiency of those runways. Winter and summer. the brown mice are active in their constant hunt fol seeds, grains, and beetlos. 


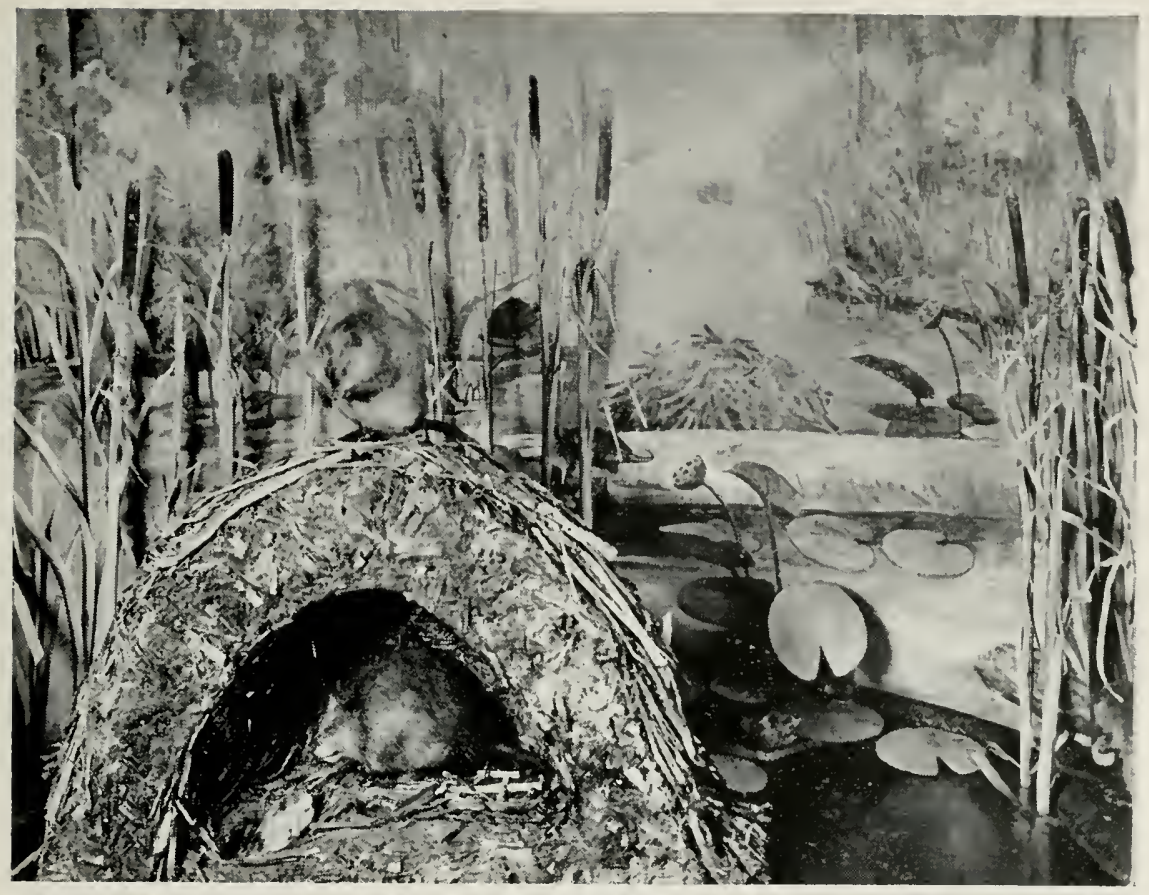

THE MUSKRATS

(Ondutru zibethicus)

Where the pond merged with the swamp, a hmmp) of anth and stirks rose above the water, the muskrats' new winter house. As antmmm movel toward winter, the brown furry animals put the finishing fouches on the home which would shelter them dming the long cold months. It looked rery much like a beaver lodge but was smaller, a conical heap of sticks and muil berhaps fom feet in diameter, plastered and matted together. Inside was a room. perhaps several rooms, and a sloping inner passage which went down into the water. This was the only exit and entrance.

At last there comes freezing weather. The muskrats stay in their house. When they are hungry, they slide down the sloping passageway into the water and here beneath the thickening sheet of ice ther find the surenlent white roots of calamms, cattail, and lotus just as they did all smmure lomer when they had to dive from the surface to get them. "The muskats do not hibermate: they eat well and sleep wamly all winter, for here om the pomel bottom lies all the abmudance of summer: and in the homac. protereted by thick walls and fostered by the heat of their own bodies. there is an alumest nnvarying temperature.

When spring comes and the ice thaws. the muskrats come ont of their mud house and once more swim abont on the surface of the poml, slap their narrow, flat, rubbery tails gaily as they dive and dive again. Soon they dig a burrow up into a shelving bank of the pond, and here in this shelter high above water the nest is made and the roung. sevelal batehes of them. are reared during the long summer. The miskrat is considered the most important furbearer in Illinois, its pelts equalling in value all others put together. 


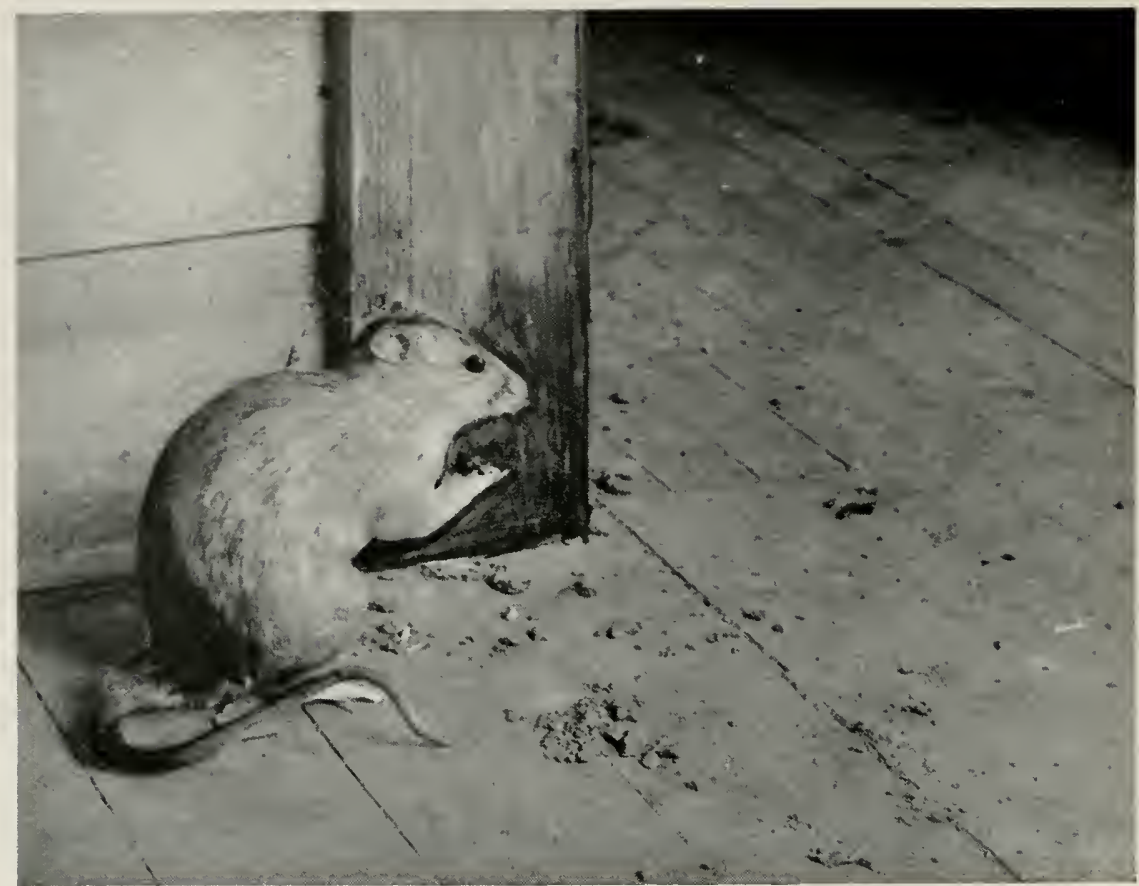

NORWAY RAT

(Rattus norvegicus)

Long ago there was a ship in a European harbor, and into it crept brown. sharp-faced, sly and secretive animals, up the mooring ropes, on to the deck when no one was watching, and down into the hold which was stacked high with chests of English tea and foodstuffs. No one knows on which ship it was. though it probably was around the year 135 , that the rats sailed away from European shores and landed in America. There had been no rats like these before on this continent.

Others followed. on all the other ships, though many did not land but -ailed back and forth and lived their entire lives for generations on shiphoarl. The rats that landed ran into alleys and cellars and wharfside honses, and there they lived, they and their roung. and the generations which followed them. By and by they spread all over the country. The Norway rat, for thousands of rears the most disliked of all rodents. perhaps of all animals, adopted America and entered every city and farm in search of food and lodging. It lived in filth and earried disease. It was responsible for outhreaks of bubonic plagne. because rat fleas are carriers of this disease. The presence of a rat in a house is like harboring a wild and dangerous inimal: sometinnes it is known to nibble the toes or fingers of sleeping babies, or hite adlults. and the bites often become badly infeeted from the filth in the rat's mouth. Men lad had good reason through the centuries to 'oathe all rats.

For it is ugly and coarse and fierce, without the dignity of a wild animal. In its dull eves there is an expresion so indieative of cold and ralculating hate- perhaps the result of its being hated loy so many generations of humankind - that a grown man. cornering a defiant rat, often will he the one ignominiously to retreat. 


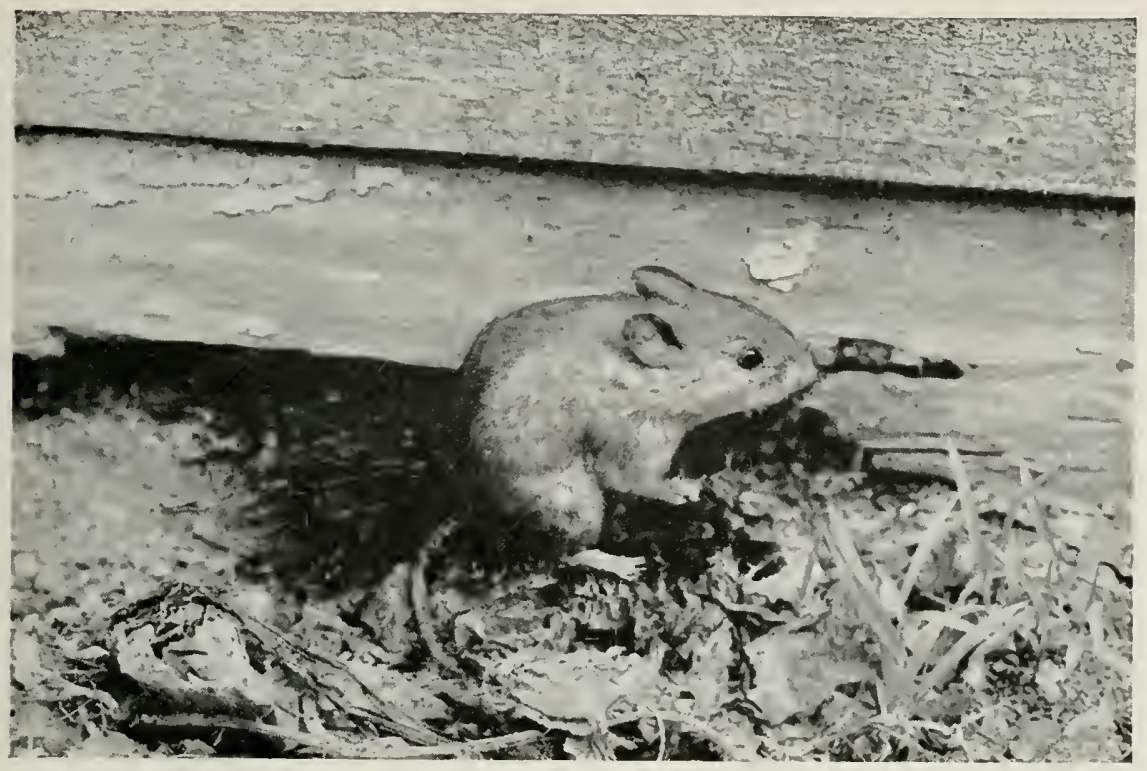

THE HOUSE MOUSE

(Mus musculus)

Through a crack that would scarcely admit a grasshopper, a little mrey mouse slips neatly indoors and, as its ancestors have done, sets itself to the business of living with men. Few houses, even skyscrapers, never have had mice as hoarders.

Very often they keep aloof and are liftle noticed for a time-just a shadow of a shape skittering behind the stove. the patter of tiny tootstejs hurrying throngh the plastering, a nibbles place on the oatmeal box. But iet them live in peace and ther assmme more than the rights of room-andboard. 'They grow bold. 'Ther jun abont in the kitehen at night evon when the cook is getting supper: they peer ont from the corners. bright eyes like black beads. whiskers a-twiteh. watehing for a combs. And any food left outside a motal cupboard at night is sampled by morning. 'Then, if not before. the honsewife buys a trap or two, and for a time rids her homsehold of mice. But they will retmm.

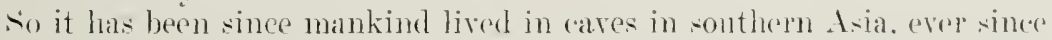
nan stepued $11 p$, a little at a time, and bettered his living anditions. Itith hins. everwwere he went, the mice went. too, and alapted themselves neatly to any situation in which man found himself. Many a monso has bern il friend to a lonely peet or artist, and at least one momse was immortalized by one of the fomely artists and hecame an international porsonality. Ilonse mice have travelled around the world and lack aguin. Fomme it is sald, are

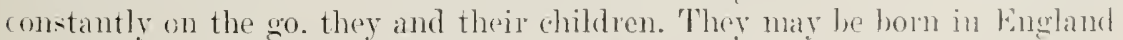
and die in America. and their descendants may go to ('hina or samua or siam. They travel on laileoad trains ant in eamel trains. in arplanes and submarines. The lowly monse, hmmble and shumed, since man s berginning shared its life with him. and dombtless will contimas to do so whether he lives in skricrapel or (ave. 


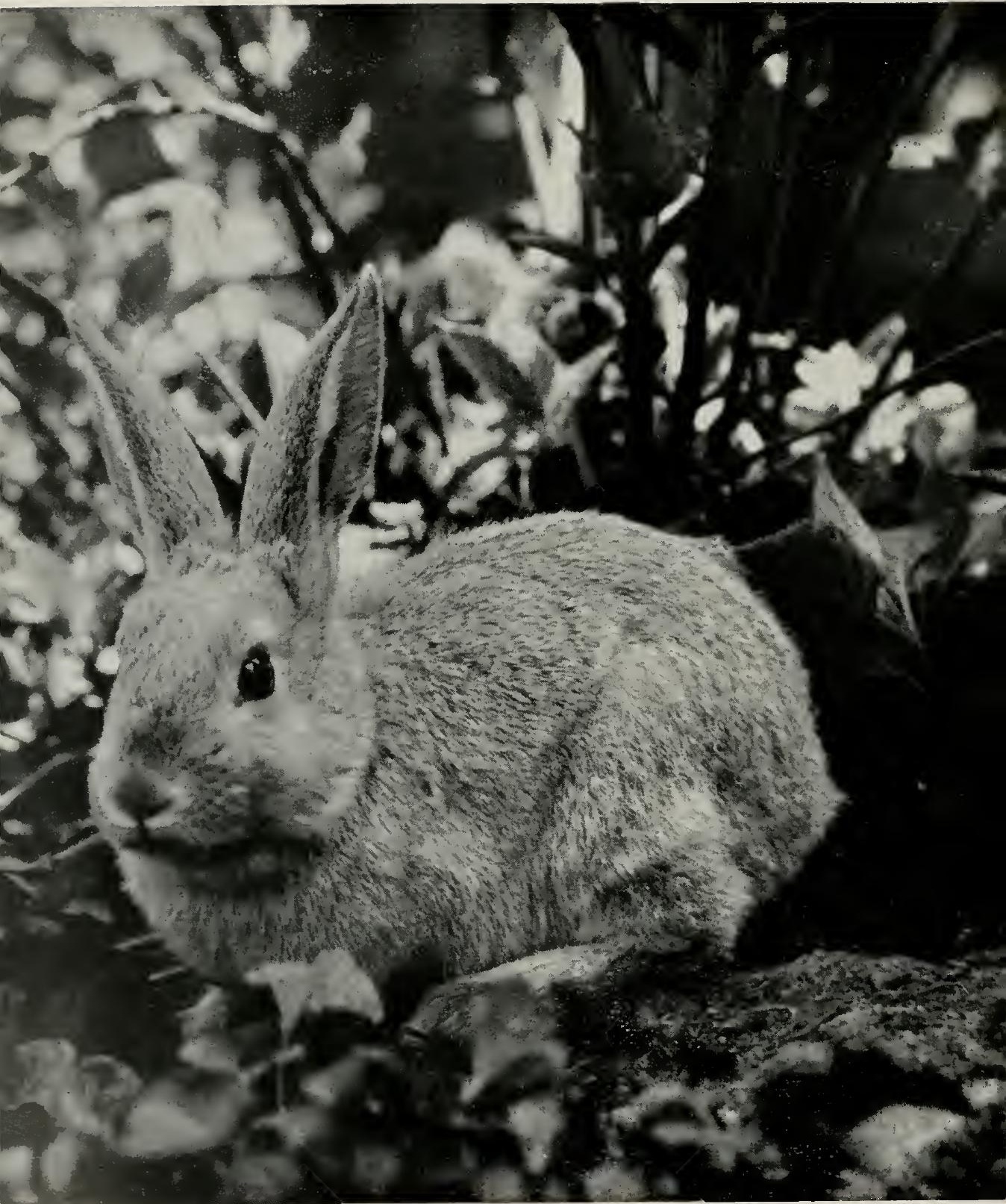

\section{THE RABBITS}

(Sylvilagus floridanus)

In April there are young rabbits out in the world. Perhaps they were born in a grass-covered nest under the gooseberry bushes in the back garden, perhaps in a hollow under an old log in the woods. They are soft, fuzzy things, ret most of them survive and grow quickly to adulthood. Then when 
the summer moon is full and bright. illuminates the leep shadows uf the maples and puts an unreal hrilliance over everything. rabbits old and young come out and skip gaily in strange dances. The moon gleame on whitr thety tails and picks ont the soft coppery crleam of wide eres. There is much tlipping about of hind legs a -haking of eas. a reckles nibluling of peas and cabbages in the neare-t garden. Or a rabhit may sit moright with offt paw: presed close to a fumr busom. and. With a my-tic expre-sion. ere the moon. The rabbit has no permanent home or shelter: when it rests. the rabbit sits in a clump of gras. Works down into it until a cupped furm is made. and sits there in confidence that it is well concealed. so toothome a mor-el for mink and weasel. hawk and owl. fox and dog. must know how to keep away from humgry mouth. It may concral itrelt in full view of the enomy or take to its heels. It may he soft and helples in appearance. but the rabbit manage-generally to preserve it-life and keep the rahbit world from decline.

In winter we really begin to see the extent of the rabbit population by the numbers of tracks they leare. After a night of winter moonlight. the snow in thicket and cornfield is so interlaced with lanes that the tracks themselves are hlurred. Left-orer com in the field is thewed: fruit tress are gnawed for the sweet immer hatk, and every available hit of food i- gleaned by the hunery rablist. 
The story of the Illinois mammals groes hack so far into the dim paist that no man saw some of them. It is only knom that they lived here heraluse of the bones and forsils which remain in the earth far beneath the surfare of town and field. Amost everywhere in Illinos are evielences of the past. In unexpeetedly common places are remains of the populations of aninals which lived and died and left only these pemmants to tell of their presence.

The story goes back on far that no one cain se it clearly. There were $n 0$ mammals in those dars; as the climax of the animal wotd. they came much later. Those earlier animals were invertebrates that swam in the oceans which once covered much of Inlinois. Sea lilies, cuttlefish. snails, clans, and other marine creatures occupied the seas in such large mumbers that when they died their limey bodies sank to the sea-bottom, stacked np and w!p. were jushed down by the weight of the water and time. and solidified as limestone. When the seas went away, the limestone beds stood np as great diffs - those along the Illinois and Missisippi Rivers alre someand in them, turned to stone, are the shells and petrified bodies of those early creatures. 'They form the background for the animals which ame nuch later.

When the vast forests of tree ferms grew in the hot swamps of Illinois and later laid down deep black beds of coal, other animals lived in the smmshine or in the stagnant waters. There were the ancestors of horseshoe crabs and rockroaches; there were dragonflies and spiders. And still there were no manmals on the eartls, none in fllinois.

Ages passed. slowly, with the changes that come orer great periods of time. Seas came and went. The coal beds sank and rocks lose up. Then ame glaciers. They moved ont of the north, slowly, for ages, changing the climate, sending wamth-leving creatures sonthward. By that time there were birds and mammals. While the ice stood hundreds of feet high wer part of Illinois. there could bo no animal life. but when the ice melted, laving wet land and new greenery. there came manmals like none which are here torlay. Yet they were enongh like certain modern animals to find in them something faniliar and recognizable. These were forermmers of modern forms.

Herds of musk-oxen, like those that still roam here and there in Greenland. trotted over the green tundra and grazed on moss and grass. The musk-ox was something like a small bison, with low-shng head, long. shaggy (nat, and horms that curved down close to the face and jutted ont in formitlable spikes. The shaggy littlo musk-oxen were well fitted to live in the cold climate of fllinois following the retreat of the last glacier. They conld light off the attacks of wolves that lived in the forests along the sangamon.

Einormous bearers were here ton. They were almost three times the size of today's heavers, but probably they had many of the same habits. Perhapes as spring came on, the giant beavers. with their great orange incione tereth, gulawed down cottomwookls and mide great dams to hold batek streams, and thes created ponds of still water. 'These beavers are known to have lived near. Clear Lake in Sangamon county: a few years ago their bones were fombl far down in the gravel of the lake. 'There were ancient turtle remains there, tor. and primitive types of fish. Deer lived in the region, and in thow dars they feared no man. Herane still there were no men in the Illineis: (ountry.

But there were elephants-the ancestors of modern elephants. Perhaps they trod heavily orer the little hill where the state capitol now stands. 
drank at the long-gone creek. trumpeted as elephants do, and mored on. and ried, here and there. 'These were the mammoths. "Their bones tell of this amazing past. Unexpectedly today, when a ditch or a well is ding, or when a sewer is put in far below gromul. the diggers may strike something hard. Perhaps ther stop work and go at it calefully: perhaps they find a huge vellowed irory tusk, enomous leg bones, perhaps a skull so large that it hardly seems like one. This has happened here and there throughont Illinois. It is ample proot that once there were wild eleplants difforent from any elephants today.

They went away, and so did the musk-oxen and the giant bearers. ()ther animals occupied the Illinois country, and at last there were men who moved in from other places, copper-simmed men who came in dugont canoes 11) the Mississippi from the south. They hat their origin elsewhere, but for a lomy time they lived in Illinois, trek mongh of the minals for food and clothing to sustain the tribes. but did not exterminate any species. In these dars there nsually was enough for all.

Bison in enomons herds were lere: ther took the plate of the little musk-oxen. There were wolves and foxes. and in the forest were elk or wapliti, the beautiful Virginia deer. alut. sometimes in winter when the wather was severe in the north. there were moose. Black bears lived in the forests. and there were momtain lions in the canrons. And all the maller animals lived here in great abundance: their natural encmies serred to keep their nmmbers in check. Natmral enemies prevented there heing ton many labbits and not enough dover, prevented the predator from taking more than they needed for food.

White men came. 'The Indians and the big mammals went away. 'They did not belong in a land where there were cities, fams and highways, with relicles that, as rears went br, picked up greater and greater speed.

There still are animals in Illinois, but many of those that remain prefer to go about at night. It is safer then. The others, the big mammals which could not withstand the approach of civilization, are shown in the Illinows State Museum in large, natural, life gloups which tell better than words and pictures something of the past. something of the lost heritage of Illinuis. 


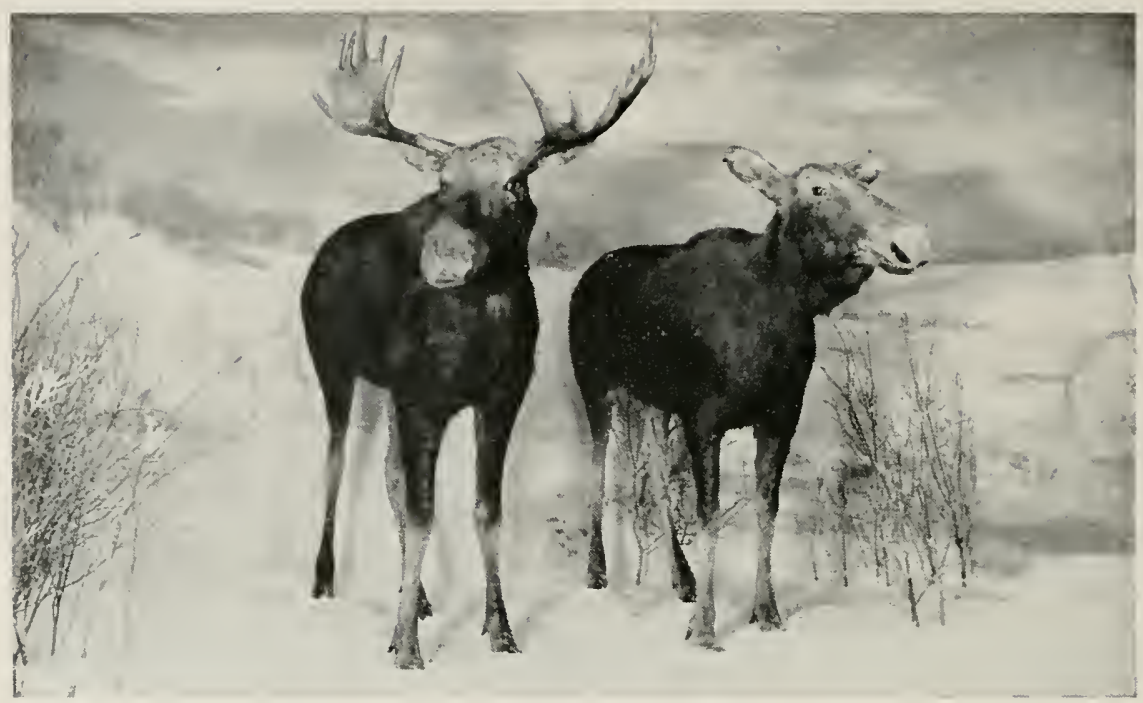

THERE WERE MOOSE IN ILLINOIS

(.17cesamericana)

Knee derp in the cold lake. the sunset gilding the ripples that lapped its legs, the hull move bent its short neck and submerged its great head to arasp a mouthful of water weeds. Behind were the dark spruess of the north (o)mtry and the bright pink blosins of fireweed under smowy birches. The white-throated sparrows piped in the bhebery bushes on the slope, and ont wor the water a loom called.

The moose lifted it: dripping muzzle from the lake bottom. pricked forward its big ears, and then went tramping off with a splashing and tearing of moderhush, one of the last truly wild creatures in America.

long ago when Amerian animals first were sen by French and English explores. Whose knowlerlge of natural history was limited solely to their homeland and to the extent of their imaginations. many were named for Enropean trpes. In knew the bear, the deer, the squirrel and the rabbit, heranse they had these things at home, but when one day the Freneh

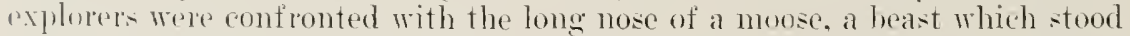
tallel than any deer, had high hmmped shomlders, and a face like nothing

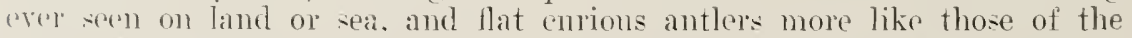
rxtinct Irish elk than anything else, the French were plainly startled. They crostured and talked and tried to explain what this heast was. hut nothing in their limited experiences conld parallel it. So they ealled it Loriginal, and ()riginal the beast remained for many yas's.

The English didn't approve of the French name, so they took the name wiven the long-legged beast by the Indians whieh. adapted to English, hecamo "monse". And the nane, sutably enough, is typically American, not horrowed from some linmean animal.

The Musem gronp shown above depicts a pair of moose as they were yatro ano in Illinois in winter. 


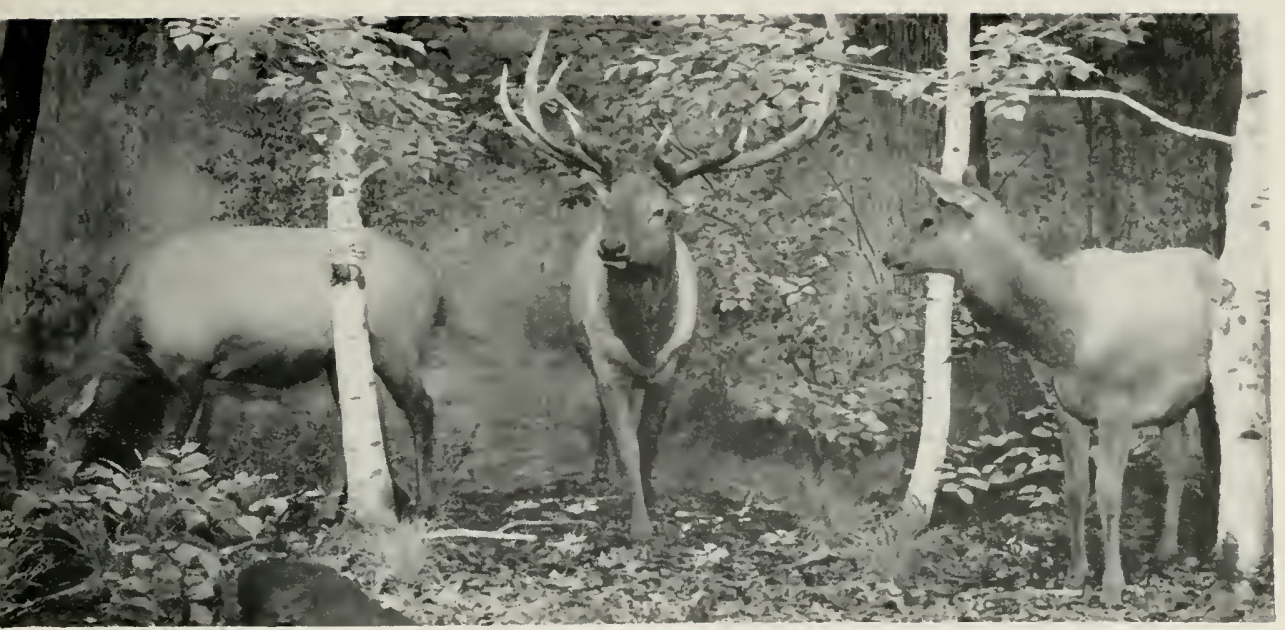

\title{
WAPITI, KING OF THE DEER
}

\author{
('emus comadensis)
}

The elk with its widely hanched antlers was master of the fores in the days when the waphiti or elk were the king deer of l]linois. They were splendid tall beasts. ret hig as they were. they could step silently: thris rellow-brown coats blender] with the forest. and when the elk were quid. they were well hidden. It was stramge that anything so large conld be so well concealed. But when the bull bos its temper and lifted a mighty hearl. bugled the challenge call to other bull wapiti. and came thundering down the hill. Lead high, antlers erashing against the tros and looking as broad as tree homghs themselres. then the whole woulland berane comscions ol the wapiti and stayed out of the way.

'The stag was owner of the herd and at all times kept areful watch that

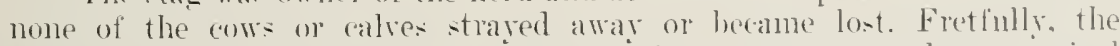
stagglers were nudged hack into place and a wary ere was hept all rival hulls. It was a point of homor. not affection but love of power. Which eansed the bull to maintain the largest heled it could command. and only a superion pival after a fierce battle could take it awar.

Jearly the huge antlers were shed and new ones grem. In spring they were covered with relrety skin distended with blowl. At this time the stags grew touchy and irritable and took ance not to solateh their paindully new antlers. But when the relrot dried, the hulls rublued their antlers andong the bushes and against trees, until the volvet foll away and the antlers were sharp and ready for a challenge.

These are no more wild wapiti or elk in Illinot: they were too big for civilization, though they still remain in a wils state in the Rockies. Thes IInsemm life-group of wapiti shows them at they noed to be in Illinois forest. 


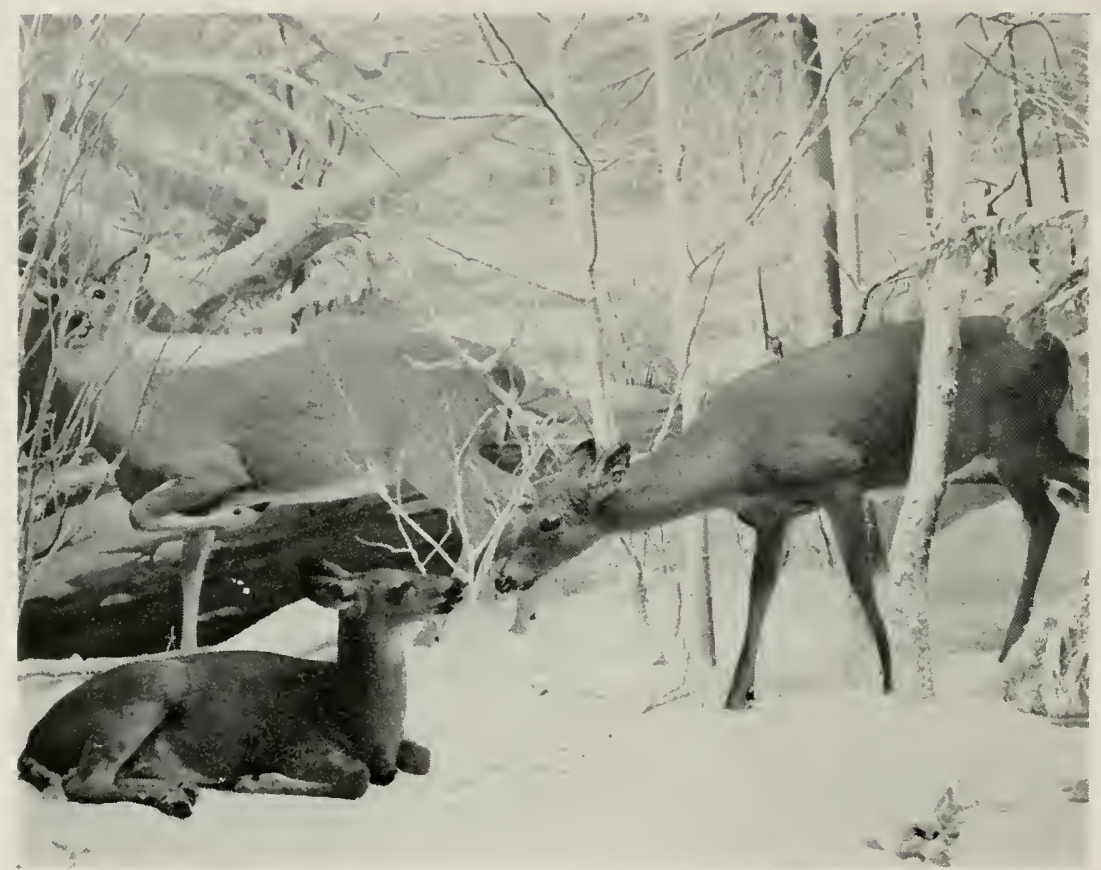

WHITE-TAILED DEER

(Odocoileus virginianus)

For years there were white-tailed or Virginia deer in the Illinois commtry. 'They pricked the snow with sharp footprints and champed the spicy green sassafras twigs when other food was scarce. The deer lived with a spring in their heels and a wildness in their hearts, and in the audacity of their freedom they often sailed neatly over the farmer's fences into pioneer barn lots, or they fed with cows in the pastures.

In the early davs when men had come to America to make a new nation, they found in the abundance of deer a source of food that was badly needed, and in deersin a material for necessary elothing. Many a time these animals stood between men and starvation and freezing. 'T'o the deer men owed much, and still they did not too greatly decimate the numbers of deer. For centuries these animals were the most important on the continent.

Deer are now present in Illinois, 3000 strong in 1950 , found principally in the north and sonth, but occasionally are reported in many other places. 'They like thickets and openings, with deep woods for shelter nearby. For deer, mulike the bison, have adapted themselves to civilization. 'This, plus sensible conservation laws on the part of mankind, has kept them in almost their original abundance in many states. In New England and other northern states they are still common and rather tame because they seem to know that, cxcept for the short weeks of the legal humting season, they are the pampered darlings of the forest. Even to protect his crops. a man may not shoot a deer out of season, and in some localities, when a log barks at a wild deer, the dog's owner may be liable to a fine.

Deer are constantly wary, ever alert. Startled, they raise their heads. Hutter thein long ears, then with a whisk of a white tail, a sudden leaping on long slender legs-the deer are gone. 


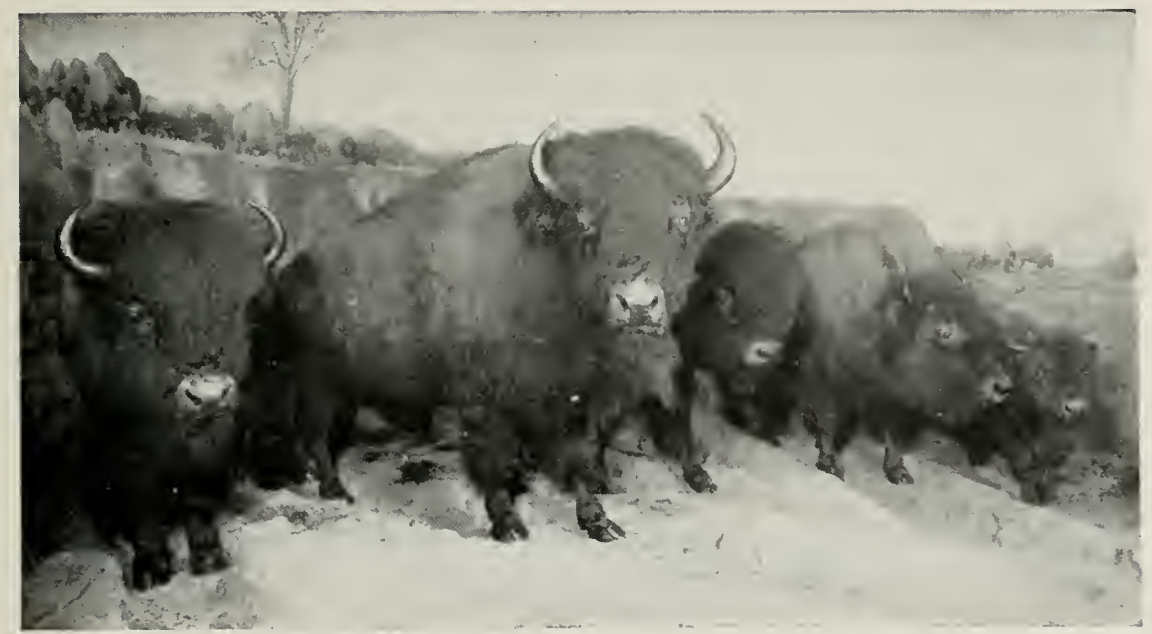

THE BISON IN ILLINOIS

(Bison bison)

The brown Sangamon moved past its willow-bound banks, past a kingfisher sitting on a stub, past trumpet vines tangled on the slopes. Up on the bluff the cottonwoods clattered their hard leaves in the hot summer wind, and far away there was a low mutter of sound, a rumble like thunder, though the sky was clear. The herd was coming. Bison-suddenly they were on the lim of the bluff. The kingfisher screamed and flew down river as, like a relentless stream of black lava, the herd poured on well-worn paths down to the water. The dust rose high; the hard hooves thundered on baked river mud; the river was roiled with plunging bodies that doused themselves and drank, and rolled in the dust and mud. Above the thunder rose the bleat of calves and spike-bulls; the river's edge was jammed.

All this happened long ago along the sangamon, as it was happening over much of the comntry from the Great Plains to the shores of the Potomae and the Susquehamna. In those early days the bison mumbered more than sixty million. 'The land was theirs.

The known story of the Ameriean bison or buffalo goes hack to Montezuma's menagerie in Mexico City where Cortez, first of all white men, in 1521 saw the bison. "It is the greatest rarity." he said in awe. "the Mexican bull, a wonderful composition of divers animals. It has erooked shoulders, with a bunch on its back like a camel; its flanks dry : its tail large; and its neck covered witl hair like a lion. It is cloven footed, its head armerl like that of a bull. which it resenbles in fierceness. with no less strength and agility.".

There were few other reports until Marquette and Jolliet paddlod up the Illinois river in 1633 , and saw great herds of wild bisun feeding on the Illinois prairie. In those days the bison were everywhere.

But the great beasts were doomed. The Indians always had killed them, but did not eut down the herds as the white men were doing, and so there were still a great many bison in lllinois until the latter part of the eighteenth century. But during that time there oceured at least two terrible winters. One eame in $1 \% 68$, the other ten rears later. Of the winter of 'is 
it is known that the snow fell for day, became rery deep, and formed a erust that would hold a man. 'The bison had not yet gone south; they were terrified and ronfused in the blizzarl, and like lost sheep they milled around in the driving whitemes nutil many dropped in their tracks, were frozen or trampled. The snom lastort so lomg that all food was covered and the bison stared. 'The deep suow that tortuled the men at Valley Forge that rear rovered the tragerly of the lllinois bison.

sipring eame, the prairie was green again. A few sclawny bison with holkw siles were seon going westward near Peoria and Galena. and elsewhere in the state. It was said that as they approached the careasses of those that had perished during that hard winter, and which lay in great numbers on the prairie, they stopped. pawed the gromml, and bellowed, so the story woes. aud then started off again to the west. In 1 iso they were swimming the Illinois river in large gromps, all heading west, and many crossed the Misissippi at Quincy. The bison in Illinois had heard the sentence of death. 'The Winter of the I)ep, snow had done an irreparable damage. and white men's guns were finishing what the elenents hegan. The last bison in Illinois is believed to have heen shot by one Sammel Aincs in 1838 near the town of Troy Grove.

A restoration of bison in their more abundant days along the sanganon is show in the main hall of the Musem. 


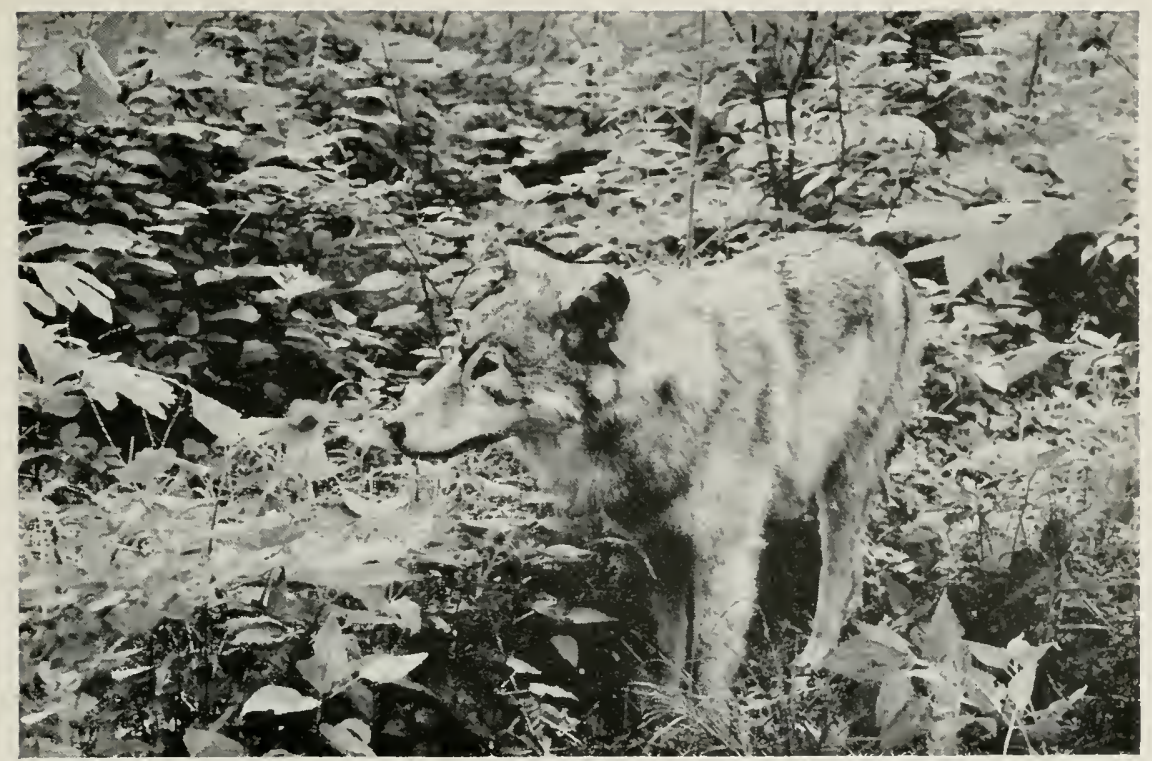

\section{TIMBER WOLF}

\section{(Canis mulitus)}

It was a cold night with brilliant stars in a back sky, and at the odge of the forest the wolves were howling. It was an reric. frightening sound, a long smooth hullooooo-and then, alyruptly, it ehanged. The voices broke into a dog-like barking-lonk and how], bark and howl-and off they went on their swift feet into the gli-tening winter darkness. The man in the doomay of an Illinois maine cabin thankfully heald them go. 'They were on the scent of game. wild game probably, and, as the roines faded into the distance. he knew that for a little while longer his sheep were sate.

But in those days the wolves came back again and again, day and night. as long as the smeli of sheep was alont. For a lomer time molves did mot bother pioneer livestock. Bur once wolves were dyiven by lumger to strike down a bar-ing old ewe and knew the taste of mutton, the shearp-lanisens on Illinois became desperate over the situation. In .January. 18:1, a newspaper in the region of Roodhouse and White Hall annomered that wohres weres about in such large numbers that they must be pxtominated or sherplatising must be abandoned.

It has been a long time since there were wolves in Thinois. thom nh now and again reports are received of timber wolves sighted and shot, ('s)ecelally near the Mississippi. The lean, grey, dog-like animals with their speedy low which could outrum most dogs. finally were ousted from the neighborhood of sheep farmer and pig rasers. The few remaining wolves, the smaller consins called covotes. live in the wildest portions of Illinois mutil they, too. are taken for the bounty which is on their leads and the wildenes which they represent. 


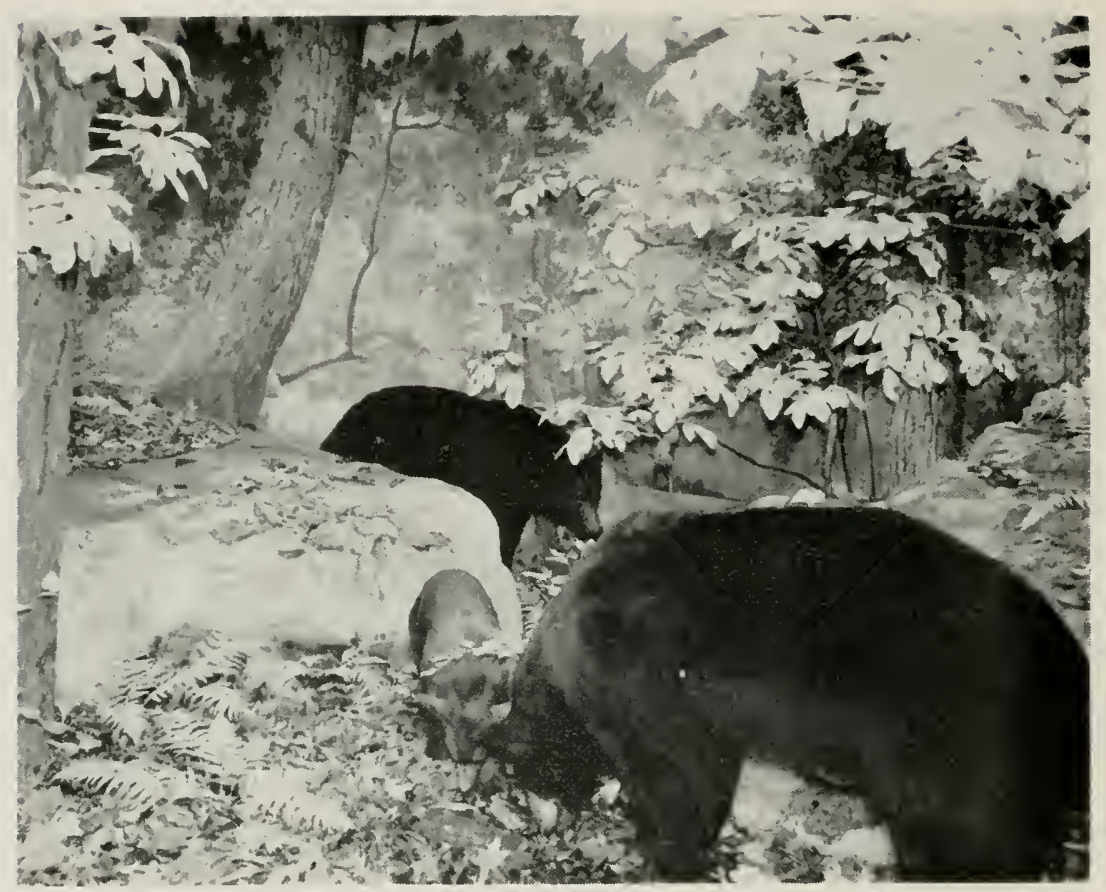

\section{BLACK BEARS IN ILLINOIS}

\section{(Euarctos americanus)}

A seant hundred years ago there were hears in lllinois. as many a valiant pioneer woman could tell. It was often she who heard a noise in the smoke house where the winter's precious hams were euring, and, looking ont, saw a bear. It was she, many a time alone in the mairie cabin, who took down the family's Kentuckv rifle from the mantel shelf and fired it point blank at the intrucler, and later proudly recounted the whole story to grandchildren who lolled on a hear-skin rug.

Bears seldom were a menace in winter. By the time the leaves had fallen and food was scarce. hears had eaten so much that, in arldition to their form-inch layer of fur, they had a correspondingly thick layer of fat on which their sleeping bodies could subsist all winter. Hibernation saved wear-andtear on a hungry bodr. prevented the eraving for food, and provided for existence through weather in which many another animal went hungry.

The fenales holed in early, for the tiny young were born in mid-winter in the hibernation den. Ilales often came out in mild weather. Almost any kind of fool would do when at last they emerged in spring, for a bear likes nearly everything gleen grass. wild berries, tasty roots, wild honey, and ants, frogs. fish. nnil carrion, and, when it can catch then, small animals and birds.

'The life group in the Musem shows a family of black bears as they once lived in Illinois. In the wild, forested area known today as Starved liock, a mother bear and two cubs one October day found a patch of red jartridge berries on the canyon floor. At that moment a large male black bear rounded a curve of rock and confronted the family. Since male bears seldom associate with their families, very likely the female turmed and snarled at the newcomer, who, disliking a fuss, ambled off. 


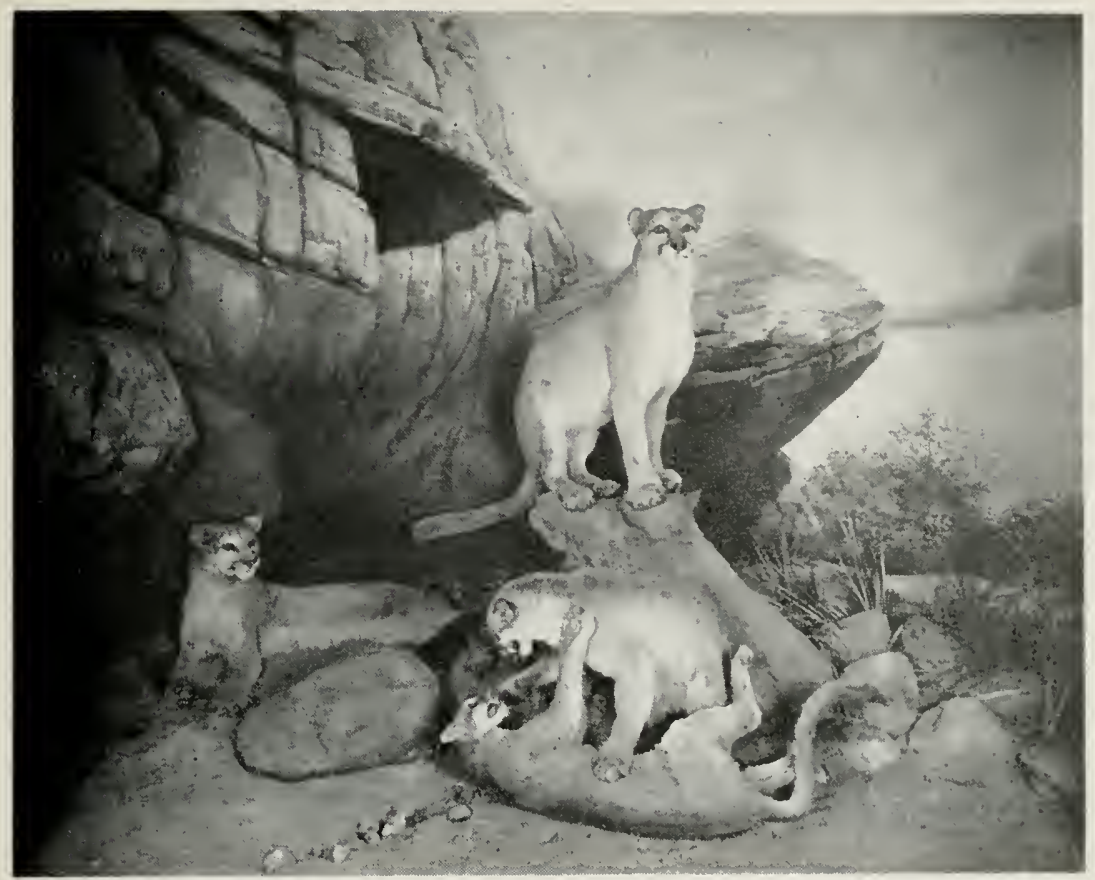

\section{"VARMINTS IN THE TIMBER"}

\section{(Wountrin Lion-Felis cougar)}

A long, lean, tawny wat had meaked into the barnyard at dusk and piekes up a young shoat that let out a terrified squeal. 'The eat bit doeper and the pig was quiet.

"That vamint's at the pigs again!". 'The farmer in the kitchen leaped for his gmon. 'The light from the open door fell across the barnyard and in its path the great tan eat paused for a moment, its eyes burning. 'Tloe farmer fired and the cat leaped lightly into the air and ranisbed in the tarkness. The shoat was gone, too, and the farmer, raging. went indoors again.

The pioneer famer knew the at as congar. panther, painter, caltamount, cat o'momntain, or varmint. knew it as a big sneak-eat that sometimes erept on its belly into sheep pens and farm yards. Yet it did not spend much time around man and his possessions: it preferred a rabhit or a grouse or a woodchuck to lambs and shoats. It was a stealthy beast. persistent to the point of mania when it had its mind ret on a meal. It woulul ereesp into impossible places and wait for its prey. The congall was a hig tom-cart with a blood-lust, and it was the terror of the forest. ()nly oreasionally in the comutryide did it acuuire a taste for the farmer"s stock.

There have been no congars for many years in Illinois. In the west they still survive, but in the rocky bluffs along the Illinois there are no more? yellow-tan cats that hurl a blood-eurdling seream against the echoing rock: 'There are no more varmints in the timloer. And yet. now and then, there are huge eat tracks in the mud ... sometimes there are unidentified screams in wild country at night. Tarmints?

The Musemm': life-group depicts a fanily of cougars at play in one of the canyons at Starred Rock State Park. 


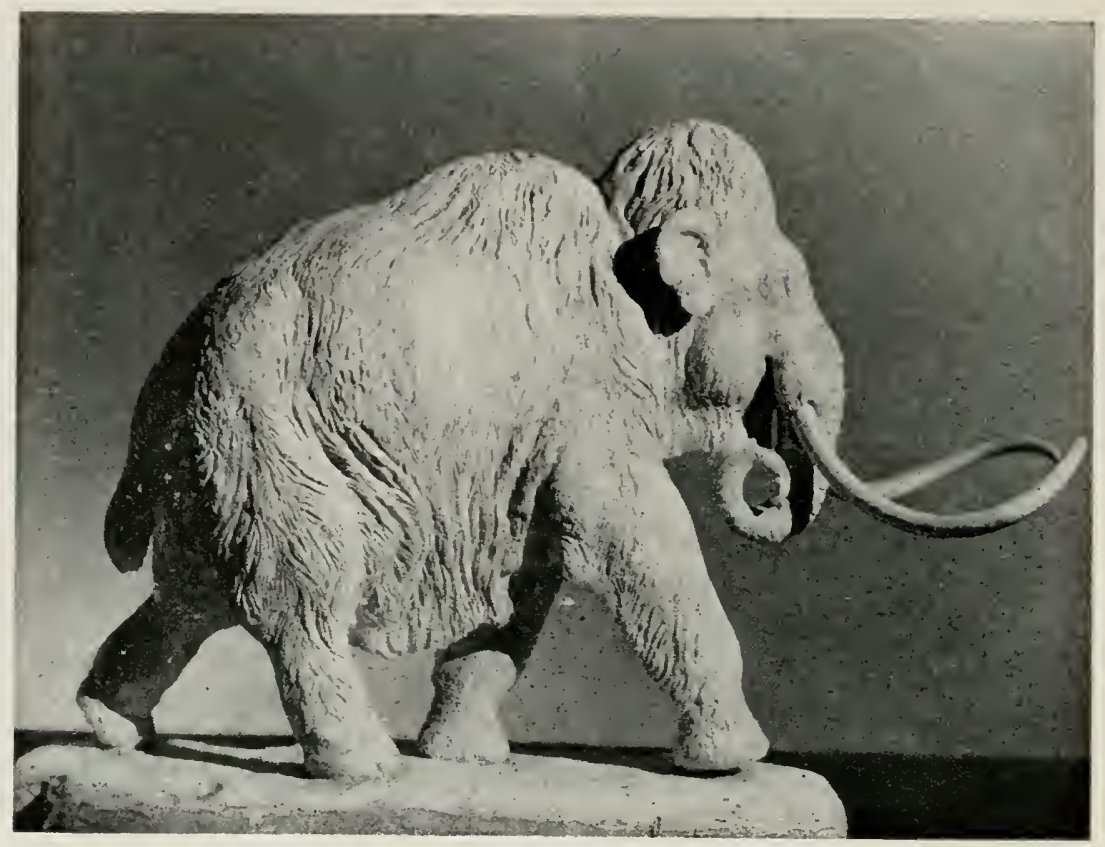

\section{THE STORY OF THE MUSEUM'S MAMMOTH}

The mammoth (Mammonteus) went the way of its ancestors ten to twenty thousand years ago, and it is believed that earliest men in Illinois knew the mammoth well, may actually have hastened it into oblivion.

Some 20,000 years ago when the retreating glacier released a torrent of melting snow and ice that swelled the rivers to great size, a mammoth lost its footing on a shelving bank and plunged into the flood somewhere along the Ohio or the Wabash. It drowned-it probably hadn't a chanceand the rushing water moved the ponderous bulk and gradually took it downstream, tumbling and dragging, the flesh wearing away as the fishes dined. By and by what was left of the mammoth lodged against a gravel bar jutting into the river and here the giant's bones came to rest.

Ages passed. An Illinois village grew up on the river banks but no one in Golconda suspected that a giant elephant thousands of years old lay buried at the town's very doorstep. And then, one day gravel excavators found a huge tusk of real ivory and sent a hurry-call to Dr. A. R. Crook at the Illinois State Museum. The people of the town were excited. No one seemed to know whether this was a creature left over from Noah's Deluge or an elephant which, as some hastily recalled, had been lost overboard from a circus boat.

Today in the Geology Room of the IIuseum there are the skull, tusk, and bones of this elephant of ancient times, and a reconstructed model of its body to show how the Illinois mammoth looked long ago. 


\section{ILLINOIS MAMMALS ARE PROTECTED BY LAW}

The Game Code of Illinois, enacted in 1941 as amended in $194 \%$ and in 1949 protects game and fur-bearing mammals, as well as song and game birds*. The Game Code is administered by the State Department of Conservation. Senate Bill No. 480 provides:

"Section 21. Protected Species-Definitioxs.] This Act shall apply .... to wild animals and parts thereof, which shall inelude their green hides, in the State of Illinois, or which may be brought into the State of Illinois, which are hereby defined as follows:

. . . GAME ANIMALS-Cottontail rabbit, Sylvilagus florilanus; Swamp rabbit. Sylvilagus aquaticus; Jack rabbit, Lepus townsendii ; Fox squirrel, Sciurus niger; Gray or cat squirrel, Sciurus carolinensis; Whitetail deer, Odocileus [Odocoileus] virginianus. FUR-BEARING ANIMALA-Opossum, Didelphia virginiana ; Raccoon, Procyon Lotor; Mink, Mustela vison; Otter, Lutra canadensis: Skunk. Mephitis mephitis; Muskrat, Ondatra zibethica; Bearer, Castor canadensis; Red fox, Vulpes fulva: Badger. Taxidea taxus.

"It is unlawful to take any said . . . wild animals and parts thereof, including their green hides, with such derices.** during the protected seasons and in such manner, as defined in this Act."

$\mathrm{By}$ law there is no open season for taking beaver, luadger or otter at any time, and no open season is provided for the whitetail deer, none of which can be killed legally.

For open seasons on game and fur-bearing mammals, see "Game and Fish Codes of Illinois". Department of Conservation, Springfield, Illinois.

For laws on song and game birds, see "Invitation to Birds", Illinois State Inseum, page 63.

* The laws protecting Illinois Mammals are found in Sellate Bill No. 575 approved July 16,1941 , Laws of Illinois, 1941 , Vol. I, pp. $767-79 \overrightarrow{7}$, anended by Senate Bill No. 373, approved July 21, 1947, Laws of Illinois, 1947, pp. 1039-1057 and further amended by Senate Bill No. 480, approved August 3, 1949, Laws of Illinois, 1949, pp. 969-983; or Revised Statutes, 1949, Volume I, pp. 2030-2048.

** Section 46-Mechanical devices-Illegal methods: snare or snare-like device, any mechanical device. smoke or other gases, ferret or other animal used in similar manner, spear or any like device, poisons, chemicals, explosives, to set fire, spring trap with jaw spread larger than six inches, lights of vehicle, shotgun larger than ten guage, shotgun capable of fring more than three consecutive shots, silencer or other device to muffle or mute sound, device for tree climbing. 


UNIVERSITY OF ILLINOIS-URBANA 507IL61ST STORY OF ILLINOIS SERIES. SPRINGFIELO 21952

COO6

30112025311025 